\title{
Atmospheric oxidation in the presence of clouds during the Deep Convective Clouds and Chemistry (DC3) study
}

\author{
William H. Brune ${ }^{1}$, Xinrong Ren ${ }^{2,3}$, Li Zhang ${ }^{1}$, Jingqiu Mao ${ }^{4}$, David O. Miller ${ }^{1}$, Bruce E. Anderson ${ }^{5}$, \\ Donald R. Blake ${ }^{6}$, Ronald C. Cohen ${ }^{7}$, Glenn S. Diskin ${ }^{5}$, Samuel R. Hall ${ }^{8}$, Thomas F. Hanisco ${ }^{9}$, L. Gregory Huey $^{10}$, \\ Benjamin A. Nault ${ }^{11, a}$, Jeff Peischl ${ }^{12,13}$, Ilana Pollack ${ }^{12,13, b}$, Thomas B. Ryerson ${ }^{13}$, Taylor Shingler ${ }^{14,15}$, \\ Armin Sorooshian $^{16,17}$, Kirk Ullmann ${ }^{8}$, Armin Wisthaler ${ }^{18}$, and Paul J. Wooldridge ${ }^{7}$ \\ ${ }^{1}$ Department of Meteorology and Atmospheric Science, Pennsylvania State University, University Park, PA, USA \\ ${ }^{2}$ Department of Atmospheric and Oceanic Science, University of Maryland, College Park, MD, USA \\ ${ }^{3}$ Air Resources Laboratory, National Oceanic and Atmospheric Administration, College Park, MD, USA \\ ${ }^{4}$ Department of Chemistry and Biochemistry, University of Alaska, Fairbanks, Fairbanks, AK, USA \\ ${ }^{5}$ Chemistry and Dynamics Branch, NASA Langley Research Center, Hampton, VA, USA \\ ${ }^{6}$ Department of Chemistry, University of California, Irvine, CA, USA \\ ${ }^{7}$ Departments of Chemistry and Earth and Planetary Sciences, University of California, Berkeley, Berkeley, CA, USA \\ ${ }^{8}$ Atmospheric Chemistry Observations and Modeling Laboratory, National Center for Atmospheric Research, \\ Boulder, CO, USA \\ ${ }^{9}$ Atmospheric Chemistry and Dynamics Branch, Goddard Space Flight Center, Greenbelt, MD, USA \\ ${ }^{10}$ School of Earth and Atmospheric Sciences, Georgia Institute of Technology, Atlanta, GA, USA \\ ${ }^{11}$ Department of Earth and Planetary Sciences, University of California, Berkeley, Berkeley, CA, USA \\ ${ }^{12}$ Cooperative Institute for Research in Environmental Sciences, University of Colorado, Boulder, CO, USA \\ ${ }^{13}$ Earth System Research Laboratory, National Oceanic and Atmospheric Administration, Boulder, CO, USA \\ ${ }^{14}$ Science Systems and Applications, Inc., Hampton, VA, USA \\ ${ }^{15}$ Atmospheric Composition Branch, NASA Langley Research Center, Hampton, VA, USA \\ ${ }^{16}$ Department of Chemical and Environmental Engineering, University of Arizona, Tucson, AZ, USA \\ ${ }^{17}$ Department of Hydrology and Atmospheric Sciences, University of Arizona, Tucson, AZ, USA \\ ${ }^{18}$ Department of Chemistry, University of Oslo, Oslo, Norway \\ ${ }^{a}$ now at: Cooperative Institute for Research in Environmental Sciences, University of Colorado, Boulder, CO, USA \\ bnow at: Department of Atmospheric Science, Colorado State University, Fort Collins, CO, USA
}

Correspondence: William H. Brune (whb2@psu.edu)

Received: 8 February 2018 - Discussion started: 26 March 2018

Revised: 22 July 2018 - Accepted: 24 July 2018 - Published: 10 October 2018

\begin{abstract}
Deep convective clouds are critically important to the distribution of atmospheric constituents throughout the troposphere but are difficult environments to study. The Deep Convective Clouds and Chemistry (DC3) study in 2012 provided the environment, platforms, and instrumentation to test oxidation chemistry around deep convective clouds and their impacts downwind. Measurements on the NASA DC-8 aircraft included those of the radicals hydroxyl $(\mathrm{OH})$ and hydroperoxyl $\left(\mathrm{HO}_{2}\right), \mathrm{OH}$ reactivity, and more than 100 other chemical species and atmospheric properties. $\mathrm{OH}, \mathrm{HO}_{2}$,
\end{abstract}

and $\mathrm{OH}$ reactivity were compared to photochemical models, some with and some without simplified heterogeneous chemistry, to test the understanding of atmospheric oxidation as encoded in the model. In general, the agreement between the observed and modeled $\mathrm{OH}, \mathrm{HO}_{2}$, and $\mathrm{OH}$ reactivity was within the combined uncertainties for the model without heterogeneous chemistry and the model including heterogeneous chemistry with small $\mathrm{OH}$ and $\mathrm{HO}_{2}$ uptake consistent with laboratory studies. This agreement is generally independent of the altitude, ozone photolysis rate, nitric oxide and 
ozone abundances, modeled $\mathrm{OH}$ reactivity, and aerosol and ice surface area. For a sunrise to midday flight downwind of a nighttime mesoscale convective system, the observed ozone increase is consistent with the calculated ozone production rate. Even with some observed-to-modeled discrepancies, these results provide evidence that a current measurementconstrained photochemical model can simulate observed atmospheric oxidation processes to within combined uncertainties, even around convective clouds. For this DC3 study, reduction in the combined uncertainties would be needed to confidently unmask errors or omissions in the model chemical mechanism.

\section{Introduction}

Deep convective clouds alter the chemical composition of the middle and upper troposphere (Chatfield and Crutzen, 1984). At its base, a cloud ingests air containing volatile organic compounds (VOCs) and anthropogenic pollutants emitted into the atmospheric boundary layer, lifts it to the upper troposphere where it spreads into the anvil, and is eventually mixed with the surrounding air, including some from the lower stratosphere. Inside the convective cloud, the chemical composition is transformed: boundary layer air is diluted with cleaner midlatitude air; water-soluble chemical species are scrubbed by contact with cloud particles; and nitrogen oxides are added by lightning. At the same time, shading in the cloud core extends the lifetime of certain photochemically active compounds. This transformed chemical composition profoundly alters the atmospheric oxidation in the upper troposphere.

Atmospheric oxidation is driven primarily by hydroxyl $(\mathrm{OH})$, whose concentration is strongly dependent on ozone $\left(\mathrm{O}_{3}\right)$, especially in the upper troposphere (Logan et al., 1981). Ozone is a source of $\mathrm{OH}$ through its destruction by solar ultraviolet radiation, which produces an excited state oxygen atom that can react with water vapor to produce $\mathrm{OH}$. Hydroxyl reactions with methane $\left(\mathrm{CH}_{4}\right)$ and VOCs produce oxygenated volatile organic compounds (OVOCs), including organic peroxyl $\left(\mathrm{RO}_{2}\right.$, where $\left.R=\mathrm{CH}_{3}, \mathrm{C}_{2} \mathrm{H}_{5}, \ldots\right)$ and hydroperoxyl $\left(\mathrm{HO}_{2}\right)$. At the same time, $\mathrm{OH}$ reacts with carbon monoxide to produce $\mathrm{HO}_{2}$. The reaction of these peroxyls with $\mathrm{NO}$ creates new nitrogen dioxide $\left(\mathrm{NO}_{2}\right)$, which then absorbs solar radiation to produce $\mathrm{NO}$ and $\mathrm{O}\left({ }^{3} \mathrm{P}\right)$, and $\mathrm{O}\left({ }^{3} \mathrm{P}\right)$ combines with $\mathrm{O}_{2}$ to form new $\mathrm{O}_{3}$. In the absence of nitrogen oxides $\left(\mathrm{NO}_{x}=\mathrm{NO}+\mathrm{NO}_{2}\right)$, the formation of $\mathrm{OH}$ and $\mathrm{HO}_{2}$ acts to destroy $\mathrm{O}_{3}$ through $\mathrm{OH}$ production and the reactions $\mathrm{O}_{3}+\mathrm{HO}_{2}$ and $\mathrm{O}_{3}+\mathrm{OH}$. Thus, atmospheric oxidation is strongly dependent on the chemical composition of the air exiting deep convective clouds.

Deep convective clouds transform the chemical composition of the upper troposphere in several ways (Barth et al., 2015, and references therein). $\mathrm{NO}_{x}$ produced by lightning can have mixing ratios of several parts per billion (ppbv) in the anvil downwind of convection (Ridley et al., 1996; Schumann and Huntrieser, 2007; Pollack et al., 2016; Nault et al., 2017). In addition to long-lived chemical species such $\mathrm{CH}_{4}$, carbon monoxide (CO), and alkanes, short-lived chemical species such as isoprene and its reaction products or those found in fire plumes can be rapidly transported from the planetary boundary layer (PBL) by convection into the upper troposphere (Apel et al., 2012, 2015). Convection also provides cloud particle liquid and solid surfaces, which can interact with gas-phase chemical species such as peroxides, potentially scrubbing some chemical species from the gas phase, thereby altering the gas-phase chemistry and its products (Jacob, 2000; Barth et al., 2016). The mixture of organics and nitrogen oxides forms organic nitrates, which act as sinks for both organic and hydrogen radicals and nitrogen oxides (Nault et al., 2016). This mixture of organic and hydrogen peroxyl and nitrogen oxides is calculated to enhance upper tropospheric $\mathrm{O}_{3}$ production in the range of $2-15 \mathrm{ppbv}_{\text {day }}{ }^{-1}$ (Pickering et al., 1990; Ren et al., 2008; Apel et al., 2012; Olson et al., 2012). Much of upper tropospheric $\mathrm{OH}$ and $\mathrm{HO}_{2}$ is produced by the photolysis of oxygenated chemical species such as formaldehyde $\left(\mathrm{CH}_{2} \mathrm{O}\right)$ and peroxides, which are products of organic chemical species that were lofted into the upper troposphere (Jaeglé et al., 1997; Wennberg et al., 1998; Ravetta et al., 2001; Ren et al., 2008).

Aircraft observations of tropospheric $\mathrm{OH}$ and $\mathrm{HO}_{2}$ have been compared to photochemical box models constrained by other simultaneous measurements (Stone et al., 2012). In the planetary boundary layer, measurements of $\mathrm{HO}_{2}$ (Fuchs et al., 2011) and, in some instruments, measurements of $\mathrm{OH}$ (Mao et al., 2012) are affected by interferences due predominantly to high abundances of alkenes and aromatics. In the free troposphere, where the abundances of these chemical species are much lower, measured and modeled $\mathrm{OH}$ and/or $\mathrm{HO}_{2}$ often agreed to within their combined uncertainties, which are similar to those for ground-based studies (Chen et al., 2012; Christian et al., 2017), but in most of these studies, either modeled and measured $\mathrm{OH}$ or $\mathrm{HO}_{2}$ inexplicably disagreed beyond combined model and measurement uncertainty for certain altitudes or chemical compositions (Mauldin III et al., 1998; Faloona et al., 2004; Tan et al., 2001; Olson et al., 2004, 2006, 2012; Ren et al., 2008, 2012; Stone et al., 2010; Kubistin et al., 2010; Regelin et al., 2013).

Only a few studies included $\mathrm{OH}$ and $\mathrm{HO}_{2}$ measurements to test the impact of deep convective clouds on atmospheric oxidation in the upper troposphere. During the First Aerosol Characterization Experiment (ACE-1), modeled $\mathrm{OH}$ was $40 \%$ greater than measured $\mathrm{OH}$ in clouds, possibly due to uptake of $\mathrm{OH}$ or $\mathrm{HO}_{2}$ on the cloud particles (Mauldin III et al., 1998). In a different study, downwind of persistent deep convective clouds over the United States, the ratio of measured-to-modeled $\mathrm{HO}_{2}$ increased from approximately 1 below $8 \mathrm{~km}$ altitude to 3 at $11 \mathrm{~km}$ altitude, suggesting an unknown source of $\mathrm{HO}_{x}\left(=\mathrm{OH}+\mathrm{HO}_{2}\right)$ coming from the 
nearby convection (Ren et al., 2008). During the African Monsoon Multidisciplinary Analyses (AMMA) campaign, daytime $\mathrm{HO}_{2}$ observations were generally simulated with a photochemical steady-state model, but not in clouds, where modeled $\mathrm{HO}_{2}$ greatly exceeded observed $\mathrm{HO}_{2}$ (Commane et al., 2010), suggesting $\mathrm{HO}_{2}$ uptake on liquid cloud drops.

Heterogeneous chemistry on aerosol can impact $\mathrm{OH}$ and $\mathrm{HO}_{2}$ abundances (Burkholder et al., 2015, and references therein). Typical $\mathrm{OH}$ and $\mathrm{HO}_{2}$ accommodation coefficients used in global models are 0.2 on aerosol particles and $0.4-1.0$ on ice. Results from a study over the North Atlantic Ocean indicated that the lower observed-than-modeled $\mathrm{HO}_{2}$ could be resolved by including heterogeneous $\mathrm{HO}_{2}$ loss (Jaeglé et al., 2000), but this loss did not resolve the same difference in clear air. This result differs from an analysis of in-cloud measurements over the western Pacific, which provides evidence that uptake in ice clouds has little impact on $\mathrm{HO}_{2}$ (Olson et al., 2004). However, in the same study, the observed-tomodeled $\mathrm{HO}_{2}$ during liquid cloud penetrations was on average only 0.65 , compared to 0.83 outside of clouds, and this difference depended upon both the duration of the cloud penetration and the liquid water content (Olson et al., 2006). The uptake of $\mathrm{HO}_{2}$ in liquid cloud particles was also observed by Whalley et al. (2015).

Laboratory studies show that the $\mathrm{HO}_{2}$ effective uptake coefficient for moist aerosol particles that contain copper is probably much lower than 0.01 in the lower troposphere but may be greater than 0.1 in the upper troposphere (Thornton et al., 2008). However, other laboratory studies show that adding organics to the particles or lowering the relative humidity can reduce uptake coefficients (Lakey et al., 2015, 2016). These values are generally lower than the $\mathrm{HO}_{2}$ effective uptake coefficient assumed in global chemical transport models. On ice surfaces, the $\mathrm{OH}$ uptake coefficient is thought to be at least 0.1 and probably larger (Burkholder et al., 2015). In global models, metal catalyzed $\mathrm{HO}_{2}$ destruction on aerosol particles can reduce global $\mathrm{HO}_{2}$ in a way that is more consistent with observed $\mathrm{OH}$ and $\mathrm{HO}_{2}$ (Mao et al., 2010). More recently, a global sensitivity analysis shows that modeled $\mathrm{HO}_{2}$ is most sensitive to aerosol uptake at high latitudes (Christian et al., 2017), consistent with the conclusion of Mao et al. (2010).

In this paper, we focus on the comparison of measured and modeled $\mathrm{OH}$ and $\mathrm{HO}_{2}$ near deep convective clouds and the implications of this comparison. Our goal is to test the understanding of atmospheric oxidation around deep convective clouds and in the cloud anvils. One possible effect is heterogeneous uptake of $\mathrm{OH}, \mathrm{HO}_{2}$, and $\mathrm{RO}_{2}$ around and in these clouds, which could alter $\mathrm{OH}$ and $\mathrm{HO}_{2}$. The data for this analysis were collected during the Deep Convective Clouds and Chemistry (DC3) study in 2012.

\section{Measurement and modeling methods}

\subsection{The DC3 study}

Barth et al. (2015) provide a detailed description of the objectives, strategy, locations, instrument payloads, and modeling for DC3. DC3 was designed to quantify the link between the properties of deep convective clouds and changes in chemical composition in the troposphere. This section provides information on the aspects of DC3 that relate most directly to the measured and modeled $\mathrm{OH}, \mathrm{HO}_{2}$, and $\mathrm{OH}$ reactivity.

DC3 involved several heavily instrumented aircraft, ground-based dual Doppler radar, lightning mapping arrays, and satellites (Barth et al., 2015). Studies were generally focused on areas in Colorado, Texas/Oklahoma, and Alabama that had dual Doppler radar coverage to quantify cloud properties. The field study took place in May-June 2012. The aircraft were based in Salina, Kansas, which was central to the three main target regions in Colorado, Texas/Oklahoma, and Alabama. The NASA DC-8 sampled deep convection six times in Colorado, four times in Texas/Oklahoma, and three times in Alabama. Typically working with the National Science Foundation (NSF) Gulfstream V (GV) aircraft, the DC8 would sample the inflow region to a growing cumulus cloud and then after it formed, spiral up to the anvil height $(\sim 8$ $12 \mathrm{~km}$ ) and join the NSF GV in sampling the outflow region of the same convection.

In addition, during the night before 21 June, the outflow from a mesoscale convective system (MCS) in the Midwest spread over Iowa and Missouri and then into Illinois and Tennessee. The DC- 8 sampled the outflow of this MCS starting at sunrise of 21 June, flying six legs, each approximately $400 \mathrm{~km}$ long, across the outflow roughly perpendicular to the wind and adjusting the downwind distance to account for the outflow velocity (Nault et al., 2016). The southern two-thirds of the first three legs were in a thin cirrus cloud and the rest was clear.

Most DC3 flights began in the late morning in order to be in position to sample near active deep convection occurring in the late afternoon and concluded near dusk for safety. About $90 \%$ of the flight time occurred when the solar zenith angle was less than $85^{\circ}$. Only the photochemical evolution flight on 21 June began before dawn.

The NASA DC-8 aircraft was the only aircraft that had an instrument to measure $\mathrm{OH}$ and $\mathrm{HO}_{2}$. The $\mathrm{DC}-8$ payload was quite comprehensive, thus providing detailed chemical composition, particle characteristics, and meteorological parameters to constrain the photochemical box model that is used to compare observed and modeled $\mathrm{OH}$ and $\mathrm{HO}_{2}$. Direct comparison between observed and modeled $\mathrm{OH}$ and $\mathrm{HO}_{2}$ is valid because the lifetimes of $\mathrm{OH}$ and $\mathrm{HO}_{2}$ are short: a few seconds or less for $\mathrm{OH}$ and a few tens of seconds for $\mathrm{HO}_{2}$. Thus, the analyses in this paper use only measurements from the DC-8. 


\subsection{Measurement of hydroxyl $(\mathrm{OH})$ and hydroperoxyl $\left(\mathrm{HO}_{2}\right)$}

$\mathrm{OH}$ and $\mathrm{HO}_{2}$ were measured with the Penn State Airborne Tropospheric Hydrogen Oxides Sensor (ATHOS), which uses laser-induced fluorescence (LIF) in low-pressure detection cells (Hard et al., 1984). ATHOS is described by Faloona et al. (2004). Sampled air is pulled through a $1.5 \mathrm{~mm}$ pinhole into a tube that leads to two detection axes. The pressure varies from $12 \mathrm{hPa}$ at low altitudes to $3 \mathrm{hPa}$ aloft. The laser beam is passed 32 times through the detection region with a multi-pass cell set at right angles to the gated microchannel plate detector. As the air passes through a laser beam, $\mathrm{OH}$ absorbs the laser radiation $(3 \mathrm{kHz}$ repetition rate, $20 \mathrm{~ns}$ pulse length) and fluoresces. In the first $100 \mathrm{~ns}$, the signal contains fluorescence as well as scattering from the walls, Rayleigh scattering, and clouds drops. $\mathrm{OH}$ fluorescence is detected from 150 to $700 \mathrm{~ns}$ after each laser pulse. $\mathrm{OH}$ is detected in the first axis; reagent nitric oxide (NO) is added before the second axis to convert $\mathrm{HO}_{2}$ to $\mathrm{OH}$, which is then detected by LIF. The laser wavelength is tuned on resonance with an $\mathrm{OH}$ transition for $15 \mathrm{~s}$ and off resonance for $5 \mathrm{~s}$, resulting in a measurement time resolution of $20 \mathrm{~s}$. The $\mathrm{OH}$ fluorescence signal is the difference between on-resonance and off-resonance signals. The ATHOS nacelle inlet is attached below a nadir plate of the forward cargo bay of the DC-8, and the lasers, electronics, and vacuum pumps were inside the forward cargo bay.

In clouds, cloud particles can be pulled into the detection system and remain intact enough to cause large, short scattering signals in the fluorescence channels randomly during on-resonance and off-resonance periods. Differencing these signals to find $\mathrm{OH}$ creates large positive and negative noise, which reduces the measurement precision by as much as a factor of 5. When the background signal due to these cloud particles exceeded the average background signal by 4 standard deviations, the online and offline data were removed from the data set before the analyses were performed. Less than $3 \%$ of the data were removed. The overall results for $\mathrm{OH}$ and $\mathrm{HO}_{2}$ vary less than $4 \%$ for filtering between 2 and 6 standard deviations.

The instrument was calibrated on the ground both in the laboratory and during the field campaign. Different sizes of pinholes were used in the calibration to produce different detection cell pressures to mimic different altitudes. Monitoring laser power, Rayleigh scattering, and laser linewidth maintained this calibration in flight. For the calibration, $\mathrm{OH}$ and $\mathrm{HO}_{2}$ were produced through water vapor photolysis by UV light at $184.9 \mathrm{~nm}$. Absolute $\mathrm{OH}$ and $\mathrm{HO}_{2}$ mixing ratios were calculated by knowing the $184.9 \mathrm{~nm}$ photon flux, which was determined with a Cs-I phototube referenced to a NIST-calibrated photomultiplier tube, the $\mathrm{H}_{2} \mathrm{O}$ absorption cross section, the $\mathrm{H}_{2} \mathrm{O}$ mixing ratio, and the exposure time of the $\mathrm{H}_{2} \mathrm{O}$ to the $184.9 \mathrm{~nm}$ light. The absolute uncertainty was estimated to be $\pm 16 \%$ for both $\mathrm{OH}$ and $\mathrm{HO}_{2}$ at a $1 \sigma$ con- fidence level. The $1 \sigma$ precision for a 1 min integration time during this campaign was about 0.01 parts per trillion by volume (pptv, equivalent to $\mathrm{pmol} \mathrm{mol}^{-1}$ ) for $\mathrm{OH}$ and $0.1 \mathrm{pptv}$ for $\mathrm{HO}_{2}$. Further details about the calibration process may be found in Faloona et al. (2004).

For environments with substantial amounts of alkenes and aromatics, ATHOS has interferences for both $\mathrm{OH}$ (Mao et al., 2012) and $\mathrm{HO}_{2}$ (Fuchs et al., 2011). New ATHOS measurement strategies have minimized these interferences, but these strategies were not fully developed in time for DC3. However, recent missions have shown that the $\mathrm{OH}$ interference is significant only just above forests or cities and is negligible above the PBL. On the other hand, the deep convective clouds encountered in DC3 can lift short-lived VOCs that cause the $\mathrm{HO}_{2}$ interference to the upper troposphere. Because ATHOS was still sensitive to this $\mathrm{RO}_{2}$ interference in $\mathrm{DC} 3$, we are not able to determine if this interference is affecting the $\mathrm{HO}_{2}$ observations around and in these clouds. For $\mathrm{OH}$, we will factor in the likelihood that the $\mathrm{OH}$ has an interference in the PBL above forests in the discussion comparing observed and modeled $\mathrm{OH}$.

For $\mathrm{HO}_{2}$, the correction method uses more than $1000 \mathrm{RO}_{2}$ chemical species modeled by the Master Chemical Mechanism v3.3.1 (MCMv3.3.1) and assumes that they are ingested into the detection flow tube without any wall loss. The model then calculates the resulting $\mathrm{OH}$, which is what would be detected as $\mathrm{HO}_{2}$. The calculated concentration of reactant $\mathrm{NO}$ is $\sim 3 \times 10^{13} \mathrm{~cm}^{-3}$ and the reaction time was determined to be $3.7 \mathrm{~ms}$, as verified by the $\mathrm{HO}_{2}$ conversion rate measured in the laboratory. This calculation was repeated for each $1 \mathrm{~min}$ time step and this calculated interference was then subtracted from the observed $\mathrm{HO}_{2}$, resulting in the $\mathrm{HO}_{2}$ values reported here. Observed $\mathrm{HO}_{2}$ was reduced by an average of $2 \%$, with some peaks of $10 \%$, both in the PBL and aloft. Because the model $\mathrm{RO}_{2}$ mechanisms are uncertain, the uncertainty for this correction is estimated to be a factor of 2, which increases the absolute uncertainty for $\mathrm{HO}_{2}$ from $\pm 16 \%$ to $\pm 20 \%$ ( $1 \sigma$ confidence).

\subsection{Measurement of $\mathrm{OH}$ reactivity}

The $\mathrm{OH}$ reactivity is the sum of the product of $\mathrm{OH}$ reactants and their reaction rate coefficients with $\mathrm{OH}$ and is the inverse of the $\mathrm{OH}$ lifetime. It is directly measured by adding $\mathrm{OH}$ to the air flowing through a tube and then monitoring the decay of the logarithm of the $\mathrm{OH}$ signal as the reaction time between the $\mathrm{OH}$ addition and $\mathrm{OH}$ detection is increased (Kovacs and Brune, 2001). OH can also be lost to the tube walls, so the measured $\mathrm{OH}$ reactivity must be corrected for this wall loss. The $\mathrm{OH}$ reactivity can be determined with Eq. (1).

$$
k_{\mathrm{OH}}=-\frac{\ln \left([\mathrm{OH}] /[\mathrm{OH}]_{0}\right)}{\Delta t}-k_{\mathrm{wall}}
$$


$[\mathrm{OH}]_{0}$ is the initial $\mathrm{OH}$ concentration, $[\mathrm{OH}]$ is the $[\mathrm{OH}]$ concentration after a reaction time $\Delta t$ between $\mathrm{OH}$ and its reactants, and $k_{\text {wall }}$ is the $\mathrm{OH}$ wall loss.

The $\mathrm{OH}$ reactivity is measured with the $\mathrm{OH}$ reactivity instrument (OHR), which sits in a rack in the DC-8 forward cargo (Mao et al., 2009). Ambient air is forced into a flow tube $\left(10 \mathrm{~cm}\right.$ diameter) at a velocity of $0.3-0.7 \mathrm{~m} \mathrm{~s}^{-1}$, flows past the pinhole of an $\mathrm{OH}$ detection system similar to the one used for ATHOS, and then is expelled out of the aircraft. In a movable wand in the center of the flow tube, $\mathrm{OH}$ is produced by the photolysis of water vapor by $185 \mathrm{~nm}$ radiation and then injected into the flow tube, mixing with the ambient air flow. As the wand is pulled back, the distance between the injected $\mathrm{OH}$ and the $\mathrm{OH}$ reactants in the air increases, resulting in the $\mathrm{OH}$ decay. The distance divided by the measured velocity gives the reaction time. The wand moves $10 \mathrm{~cm}$ in $12 \mathrm{~s}$ and then returns to the starting position, measuring a decay every $20 \mathrm{~s}$.

The OHR calibration was checked in the laboratory before and after DC3 using several different known amounts of different chemical species. During a semiformal OHR intercomparison in Jülich, Germany, in October 2015, the OHR instrument was combined with a different laser, wand drive, and electronics, and despite the difficulties encountered, it was found to produce accurate $\mathrm{OH}$ reactivity measurements (Fuchs et al., 2017).

The uncertainty in the $\mathrm{OH}$ reactivity measurement consists of an absolute uncertainty and the uncertainty associated with the wall loss subtraction. Changes in the OHR instrument between Arctic Research of the Composition of the Troposphere from Aircraft and Satellites (ARCTAS) and DC3 result in slightly different instrument operation, wall loss, and measurement uncertainties between this paper and Mao et al. (2009). The pressure dependence of the $\mathrm{OH}$ wall loss was measured in the laboratory using ultra zero air $(99.999 \%$ pure) and was found to be between 2 and $4 \mathrm{~s}^{-1}$ over the range pressures equivalent to 0 to $12 \mathrm{~km}$ altitude. The flow tube wall is untreated aluminium so that every $\mathrm{OH}$ collision with the wall results in complete $\mathrm{OH}$ loss no matter the environment or altitude. Mao et al. (2009) confirm the zero found in the laboratory agrees with the zero found in flight. From these laboratory calibrations, the estimated uncertainty in the wall loss correction is $\pm 0.5 \mathrm{~s}^{-1}$ ( $1 \sigma$ confidence). When the $\mathrm{OH}$ reactivity is $1 \mathrm{~s}^{-1}$, the combined uncertainty from the absolute uncertainty and the zero decay is $\pm 0.6 \mathrm{~s}^{-1}$ ( $1 \sigma$ confidence), which suggests that $90 \%$ of the measurements should be within $\pm 1.2 \mathrm{~s}^{-1}$ of the mean value.

Air entering the OHR flow tube was warmed by $\sim 5^{\circ} \mathrm{C}$ at altitudes below $2 \mathrm{~km}$ to by as much as $75^{\circ} \mathrm{C}$ at $12 \mathrm{~km}$. The flow tube pressure was $50 \mathrm{hPa}$ greater than ambient due to the ram force pushing air through the flow tube. These temperature and pressure differences can affect the reaction rate coefficients for some $\mathrm{OH}$ reactants and thus change the $\mathrm{OH}$ reactivity. In order to compare observed and model-calculated $\mathrm{OH}$ reactivity, the model was run for both ambient condi- tions and for the OHR flow tube pressure and temperature, but the observed and model-calculated $\mathrm{OH}$ reactivity will be compared for the OHR flow tube pressure and temperature.

\subsection{Measurement of other chemical species, photolysis frequencies, and other environmental variables}

Accurate measurements of other chemical species and environmental variables are critical for this comparison of measured and modeled $\mathrm{OH}, \mathrm{HO}_{2}$, and $\mathrm{OH}$ reactivity. The photolysis frequency measurements are particularly critical for DC3 because of all the time spent flying around clouds and in the deep convection anvil. A list of these measurements is given in Table 1 and is summarized in Barth et al. (2015, 2016) and Pollack et al. (2016). The list of measured chemical species includes $\mathrm{CO}, \mathrm{CH}_{4}, \mathrm{~N}_{2} \mathrm{O}, \mathrm{NO}, \mathrm{NO}_{2}, \mathrm{O}_{3}$, organic nitrates, alkanes, alkenes, aromatics, aldehydes, alcohols, and peroxides.

\subsection{Photochemical box model}

The photochemical box model used in this study is based on the Matlab-based modeling framework, the Framework for Zero-Dimensional Atmospheric Modeling (FOAM), which was developed and made freely available by Glenn Wolfe (Wolfe et al., 2016). The gas-phase photochemical mechanism was MCMv3.3.1 (Saunders et al., 2003; Jenkin et al., 2003). This model was constrained by all simultaneous measurements of chemical species, photolysis frequencies, and meteorological variables (Table 1) and then run to calculate $\mathrm{OH}, \mathrm{HO}_{2}$, and all reaction products that were not measured, such as organic peroxy radicals. Pernitric acid $\left(\mathrm{HO}_{2} \mathrm{NO}_{2}\right)$ was measured but was not used to constrain the model because few measurements were reported below $4 \mathrm{~km}$. Measured and modeled $\mathrm{HO}_{2} \mathrm{NO}_{2}$ agree to within $\sim 25 \%$ from 5 to $9 \mathrm{~km}$, and modeled $\mathrm{HO}_{2} \mathrm{NO}_{2}$ is 1.7 times that measured above $8 \mathrm{~km}$. This difference between using modeled and observed $\mathrm{HO}_{2} \mathrm{NO}_{2}$ made only a few percent difference in modeled $\mathrm{OH}$ and $\mathrm{HO}_{2}$.

A publicly available merge file provided the constraining measurements for the photochemical model (Aknan and Chen, 2017). We chose the 1 min merge as a compromise between higher-frequency measurements that needed to be averaged into $1 \mathrm{~min}$ bins and lower-frequency measurements that needed to be interpolated between $1 \mathrm{~min}$ bins. $\mathrm{OH}$ and $\mathrm{HO}_{2}$ measurements, made every $20 \mathrm{~s}$, were averaged into the 1 min bins.

Heterogeneous chemistry was added to the model for some model runs. While many chemical species undergo heterogeneous chemistry, most of the chemical species that strongly influence $\mathrm{OH}$ and $\mathrm{HO}_{2}$ were measured so that their heterogeneous chemistry can be ignored in these comparisons between observed and modeled $\mathrm{OH}$ and $\mathrm{HO}_{2}$. However, organic peroxyl radicals were not measured and their heterogeneous chemistry could have an influence on $\mathrm{OH}$ and $\mathrm{HO}_{2}$. 
Table 1. Measured chemical species.

\begin{tabular}{|c|c|c|c|}
\hline Chemical species & Accuracy ( $2 \sigma$ confidence) & Time resolution & $\begin{array}{l}\text { Reference that } \\
\text { describes the } \\
\text { instrument }\end{array}$ \\
\hline $\mathrm{OH}, \mathrm{HO}_{2}$ & $\pm 32 \%$ & $20 \mathrm{~s}$ & Faloona et al. (2004) \\
\hline $\begin{array}{l}\mathrm{NO} \\
\mathrm{NO}_{2} \\
\mathrm{O}_{3}\end{array}$ & $\begin{array}{l}0.01 \mathrm{ppbv}+4 \% \\
0.02 \mathrm{ppbv}+6 \% \\
0.04 \mathrm{ppbv}+3 \%\end{array}$ & $1 \mathrm{~s}$ & $\begin{array}{l}\text { Ryerson et al. (2000); } \\
\text { Pollack et } \\
\text { al. }(2011)\end{array}$ \\
\hline $\mathrm{HCHO}$ & $\pm 10 \%+ \pm 10$ pptv offset & $1 \mathrm{~s}$ & Cazorla et al. (2015). \\
\hline $\begin{array}{l}\mathrm{NO}_{2} \\
\text { total peroxy nitrates (PNs); } \\
\text { total alkyl nitrates (ANs) }\end{array}$ & $\begin{array}{l} \pm 5 \% \\
\pm 10 \% \\
\pm 15 \%\end{array}$ & $15 \mathrm{~s}$ & $\begin{array}{l}\text { Thornton et al. (2000); } \\
\text { Day et al. (2002) }\end{array}$ \\
\hline $\mathrm{CO}, \mathrm{CH}_{4}, \mathrm{~N}_{2} \mathrm{O}$ & $\pm 2 \%$ or $2 \mathrm{ppbv}$ & $1 \mathrm{~s}$ & Sachse et al. (1991) \\
\hline $\begin{array}{l}\mathrm{SO}_{2} \\
\mathrm{HCl} \\
\text { peroxyacetyl nitrate (PAN), peroxypropionyl } \\
\text { nitrate (PPN), } \mathrm{HNO}_{4}\end{array}$ & $\begin{array}{l} \pm 15 \% \\
\pm 20 \% \\
\pm 30 \%\end{array}$ & $10 \mathrm{~s}$ & Huey (2007) \\
\hline $\begin{array}{l}\mathrm{H}_{2} \mathrm{O}_{2}, \mathrm{CH}_{3} \mathrm{OOH} \text {, ISOPOOH, } \\
\text { glycolaldehyde, isoprene epoxydiol (IEPOX), } \\
\mathrm{C}_{5} \mathrm{H}_{10} \mathrm{O}_{3}, \mathrm{C}_{5} \mathrm{H}_{8} \mathrm{O}_{3} \text {, ethanal nitrate, hydroxy- } \\
\text { acetone, hydrogen cyanide, } \mathrm{HNO}_{3} \text {, isoprene ni- } \\
\text { trate, peroxyacetic acid, propanone nitrate }\end{array}$ & $\begin{array}{l} \pm(40-80) \% \\
\pm 50 \%+(25-100) \mathrm{pptv} \\
\text { offset }\end{array}$ & $10 \mathrm{~s}$ & Crounse et al. (2006) \\
\hline $\begin{array}{l}\text { Isoprene, monoterpenes, methyl vinyl ke- } \\
\text { tone/methacrolein (MVK/MACR), ace- } \\
\text { tone/propanal, methanol, acetaldehyde, } \\
\text { acetonitrile }\end{array}$ & $\pm 10 \%$ & $2 \mathrm{~s}$ & Mielke et al. (2008) \\
\hline $\begin{array}{l}\text { Ethyne, ethane, ethane, propene, propane, } \\
\text { i-butane, n-butane, i-pentane, n-pentane, } \\
\text { n-hexane, n-heptane, 2,3-dimethylbutane, 2- } \\
\text { methylhexane, 3-methylhexane, cyclohexane, } \\
\text { benzene, toluene, m- and p-xylene, o-xylene, } \\
\text { ethylbenzene, cis-2-butene, trans-2-butene, } \\
\mathrm{C} 8 \text { aromatics/benzaldehyde, dimethyl sulfide } \\
\text { (DMS), methyl nitrate, isoprene, } \alpha \text {-pinene, } \beta \text { - } \\
\text { pinene, several halogen-containing compounds }\end{array}$ & $\pm 10 \%$ & Variable, seconds to minutes & Colman et al. (2001) \\
\hline $\mathrm{H}_{2} \mathrm{O}$ & $\pm 5 \%$ or $1 \mathrm{ppmv}$ & $1 \mathrm{~s}$ & Vay et al. (1998) \\
\hline
\end{tabular}

Thus, heterogeneous chemistry is implemented in the model for $\mathrm{OH}, \mathrm{HO}_{2}$, and $\mathrm{RO}_{2}$, even though the uptake of $\mathrm{RO}_{2}$ is thought to be small.

The common types of particles encountered with convection are humidified submicron aerosol particles around and in the convection, liquid drops in lower-altitude clouds, and ice particles in the deep convective cloud anvil. The effective uptake of $\mathrm{OH}, \mathrm{HO}_{2}$, and $\mathrm{RO}_{2}$ onto these surfaces was found from Eq. (2).

$$
\begin{aligned}
\frac{1}{\gamma_{\mathrm{eff}}}= & \left(\gamma_{\text {surface }}+\left(\frac{1}{\alpha}+\frac{1}{\gamma_{\mathrm{sol}}+\gamma_{\mathrm{rxn}}}\right)^{-1}\right)^{-1} \\
& +\frac{0.75+0.286 K n}{K n(K n+1)}
\end{aligned}
$$

$\gamma_{\text {eff }}$ is the effective uptake coefficient, $\gamma_{\text {surface }}$ is surface reaction uptake, $\alpha$ is the accommodation coefficient, $\gamma_{\text {sol }}$ is uptake due to diffusion through the liquid, $\gamma_{\text {rxn }}$ is uptake due to aqueous-phase reactions, and the last term is the inverse of the gas-phase diffusion in terms of the Knudsen number, Kn (Burkholder et al., 2015; Tang et al., 2014). The first term on the right-hand side is the total uptake coefficient, $\gamma_{\text {total }}$. The gas-phase molecular diffusion of chemical species to the particle surface can limit the uptake, especially for large accommodation coefficients and large particles.

The total uptake coefficient for $\mathrm{OH}$ and $\mathrm{HO}_{2}$ depends on the particle chemical composition, phase, and size (Burkholder et al., 2015). While some particle properties were measured in DC3, there are unknowns in particle composition and uncertainties in trying to calculate the uptake 
coefficient for each 1 min time step. The goal of including heterogeneous chemistry in the model is to determine if heterogeneous chemistry has a substantial impact on the comparison between the observed and modeled $\mathrm{OH}$ and $\mathrm{HO}_{2}$. Thus, we will run the model with fixed values for the total uptake; if the impact on the modeled $\mathrm{OH}$ and $\mathrm{HO}_{2}$ is substantial, then we will have to improve the parameterization of the total uptake.

For aerosol particles, the dry aerosol particle radius is multiplied by the growth factor and then the area-weighted median ambient aerosol radius is determined. The surface area is found by summing the surface area in each bin, multiplying by the bin width, and then correcting by the square of the growth factor for each minute. Ice particles are assumed to be spherical and their size distribution is used to determine the median particle radius. The surface area per $\mathrm{cm}^{-3}$ of air is determined by summing the surface area per $\mathrm{cm}^{-3}$ of air multiplied by the bin width, which was provided in the merge file for each minute.

The model is then run for three different primary cases: gas phase with no heterogeneous chemistry (called "nohet"), heterogeneous chemistry (called "het") with $\alpha_{\text {aer }}=0.2$ (which is consistent with the value used in some global models) and $\alpha_{\text {ice }}=1.0$ for $\mathrm{OH}, \mathrm{HO}_{2}$, and $\mathrm{RO}_{2}$, and maximum heterogeneous chemistry (called "hetmax") with $\alpha_{\text {aer }}=1.0$ and $\alpha_{\text {ice }}=1.0$. The observed and modeled $\mathrm{OH}$ and $\mathrm{HO}_{2}$ are compared for these three cases.

$\mathrm{OH}$ reactivity was also modeled for comparison to observed $\mathrm{OH}$ reactivity. Modeled $\mathrm{OH}$ reactivity was calculated from the measured chemical species plus $\mathrm{OH}$ reactants that were not measured but were produced by the photochemical model. Examples of these additional $\mathrm{OH}$ reactants are organic peroxy, organic peroxides, and unmeasured aldehydes. Uncertainty in the modeled $\mathrm{OH}$ reactivity is estimated to be $\pm 10 \%$ ( $1 \sigma$ confidence) (Kovacs et al., 2001).

Uncertainty in the photochemical box model can be assessed with Monte Carlo methods in which model constraints are varied randomly over their uncertainty ranges and then the widths of the resulting distributions for $\mathrm{OH}$ and $\mathrm{HO}_{2}$ abundances are used to determine the model uncertainties. If just reaction rate coefficients, photolysis frequencies, and reaction products are varied, the $\mathrm{OH}$ and $\mathrm{HO}_{2}$ uncertainties at the $1 \sigma$ confidence level are typically $\pm(10-15) \%$ (Thompson and Stewart, 1991; Kubistin et al., 2010; Olson et al., 2012; Regelin et al., 2013). When uncertainties in the measurements used to constrain the model are included, uncertainties at the $1 \sigma$ confidence level are typically $\pm 20 \%$ or more for both local and global models (Chen et al., 2012; Christian et al., 2017). We use $\pm 20 \%$ uncertainty at the $1 \sigma$ confidence level for the model uncertainty in this paper, which can be combined with the measurement uncertainty of about $\pm 20 \%$ uncertainty at the $1 \sigma$ confidence level. We note that the observed-to-modeled difference for statistical significance lies approximately at the sum of the standard deviations of the mean for the observations and model. As a result, the factors of 1.4 and $1 / 1.4$ serve as indicators for agreement between observed and modeled $\mathrm{OH}, \mathrm{HO}_{2}$, and $\mathrm{OH}$ reactivity.

We decided to make the comparisons between observations for all DC3 results, including transit from Salina, KS, to the deep convection regions. Using all the data gives a more robust comparison and was found to give comparison results identical to those using data sets restricted to the radar-enhanced sites in Colorado, Texas/Oklahoma, and Alabama near the vicinity of convection. The direct impact of deep convection is also tested by examining the observed-tomodeled comparison as a function of the ice surface area per $\mathrm{cm}^{-3}$ of air. This analysis achieves the goals laid out in the introduction.

The model was run 27 times to test the sensitivity of the calculated $\mathrm{OH}$ and $\mathrm{HO}_{2}$ to different factors. First, the chemical mechanism was expanded to include the reactions of $\mathrm{CH}_{3} \mathrm{O}_{2}+\mathrm{OH}$ and $\mathrm{C}_{2} \mathrm{H}_{5} \mathrm{O}_{2}+\mathrm{OH}$ (Assaf et al., 2017), and in some cases, reactions of $\mathrm{OH}$ with the next 300 most significant $\mathrm{RO}_{2}$ species that comprise $95 \%$ of the modeled $\mathrm{RO}_{2}$ total, assuming a reaction rate coefficient of $10^{-10} \mathrm{~cm}^{-3} \mathrm{~s}^{-1}$. Adding the measured reactions decreased $\mathrm{OH}$ by $\sim 1 \%$ ( $5 \%$ maximum) and increased $\mathrm{HO}_{2}$ by $<1 \%$ (15\% maximum); adding the assumed reactions of $\mathrm{OH}$ with other $\mathrm{RO}_{2}$ species changed modeled $\mathrm{OH}$ and $\mathrm{HO}_{2}$ by less than $3 \%$. Second, the decay frequency of the unconstrained modeled oxygenated intermediates was varied from $6 \mathrm{~h}$ to 5 days. The resulting modeled $\mathrm{OH}$ and $\mathrm{HO}_{2}$ varied by $\sim 10 \%$ over this range. This decay time serves as a proxy for surface deposition in the planetary boundary layer as well as for recently measured rapid reactions of highly oxidized $\mathrm{RO}_{2}+\mathrm{RO}_{2}$ to form peroxides (Bernt et al., 2018). This decay time is highly uncertain. The mean of the model runs using decay times of $6 \mathrm{~h}$, 1 day, and 5 days and using the model mechanism including $\mathrm{CH}_{3} \mathrm{O}_{2}+\mathrm{OH}$ and $\mathrm{C}_{2} \mathrm{H}_{5} \mathrm{O}_{2}+\mathrm{OH}$ was used for the comparisons to the measurements.

\section{Results}

The DC3 chemical environments dictate the $\mathrm{OH}$ and $\mathrm{HO}_{2}$ abundances. Using all the flight data, altitude profiles of NO, $\mathrm{CO}, \mathrm{O}_{3}$, and particle surface area were collected into $0.5 \mathrm{~km}$ altitude bins and the median values were found (Fig. 1). The radar altitude is used for these comparisons because the surface elevations and thus planetary boundary layer (PBL) are at different pressure altitudes for the Colorado, Texas/Oklahoma, and Alabama regions.

Median NO exhibits a C-shaped profile with median values near $50 \mathrm{pptv}$ in the planetary boundary layer, a minimum of $10 \mathrm{pptv}$ at $5 \mathrm{~km}$ altitude, and a maximum value of $0.5 \mathrm{ppbv}$ above $10 \mathrm{~km}$. NO in the PBL was largely due to anthropogenic pollution; NO aloft was mainly due to a combination of lightning and stratospheric $\mathrm{NO}_{x}$. Median $\mathrm{CO}$ slightly decreased from $\sim 120 \mathrm{ppbv}$ near the surface to $\sim 80 \mathrm{ppbv}$ at $12 \mathrm{~km}$. Median $\mathrm{O}_{3}$ was $50 \mathrm{ppbv}$ in the PBL and then in- 


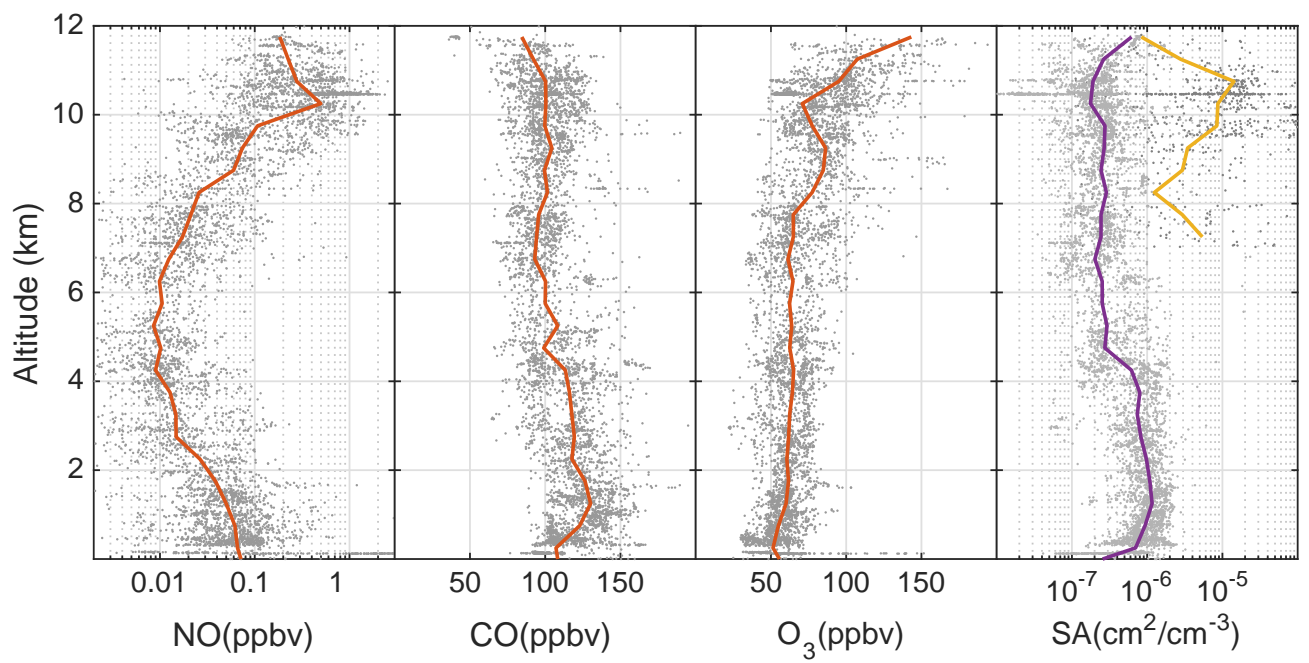

Figure 1. Altitude profiles of median $\mathrm{NO}, \mathrm{CO}, \mathrm{O}_{3}$, and aerosol (purple) and ice (yellow) surface area (SA). Gray points are individual 1 min data, while median values are represented by the lines. These data are for the entire DC3 study.

creased to as much as $100 \mathrm{ppbv}$ near $12 \mathrm{~km}$, likely due to stratospheric ozone influence. The surface area per $\mathrm{cm}^{-3}$ of air of aerosol was $10^{-6} \mathrm{~cm}^{2} \mathrm{~cm}^{-3}$ in the PBL, but was about $3 \times 10^{-7} \mathrm{~cm}^{2} \mathrm{~cm}^{-3}$ above that. Median ice surface area was as much as $2 \times 10^{-5} \mathrm{~cm}^{2} \mathrm{~cm}^{-3}$, with high variability spanning a factor of 100 .

\subsection{Comparing $\mathrm{HO}_{x}$ observations with the no-het model}

Observations will be compared to the no-het model, which should be considered as the base case; the heterogeneous cases will be considered later. When observed and modeled $\mathrm{OH}$ and $\mathrm{HO}_{2}$ are plotted against time, model results generally agree with the observed values to within combined uncertainties, with occasional periods in which the observed values can be either much larger or smaller than all the model variants. A plot of this time series of observed and modeled $\mathrm{OH}$ and $\mathrm{HO}_{2}$ includes 14 model runs with model integration times varied from 3 to $24 \mathrm{~h}$, dilution frequencies varied from $6 \mathrm{~h}$ to 5 days, and with or without including the $\mathrm{RO}_{2}+\mathrm{OH}$ reaction (Fig. S1 in the Supplement). Another way to examine these results is to plot the observed and modeled values as a function of altitude and other influential chemical species, photolysis frequency, or location.

Median observed $\mathrm{OH}$ was about $2 \times 10^{6} \mathrm{~cm}^{-3}$ from $\sim$ $3 \mathrm{~km}$ to $10 \mathrm{~km}$ altitude, but was greater than $3 \times 10^{6} \mathrm{~cm}^{-3}$ below $3 \mathrm{~km}$ and just above $10 \mathrm{~km}$, where a spike in $\mathrm{OH}$ brings the median $\mathrm{OH}$ to $3.5 \times 10^{6}$ (Fig. 2). This profile is consistent with the NO profile; for the $\mathrm{NO}$ amounts measured in DC3, increased NO shifts more $\mathrm{HO}_{x}$ to $\mathrm{OH}$. The median $\mathrm{OH}$ observed-to-modeled ratio for the no-het case is close to 1.0 at $0-4 \mathrm{~km}$, is $1.2-1.3$ between 5 and $9 \mathrm{~km}$, and $0.8-0.9$ above $10 \mathrm{~km}$. Generally, the observed-to-modeled ratio is within the

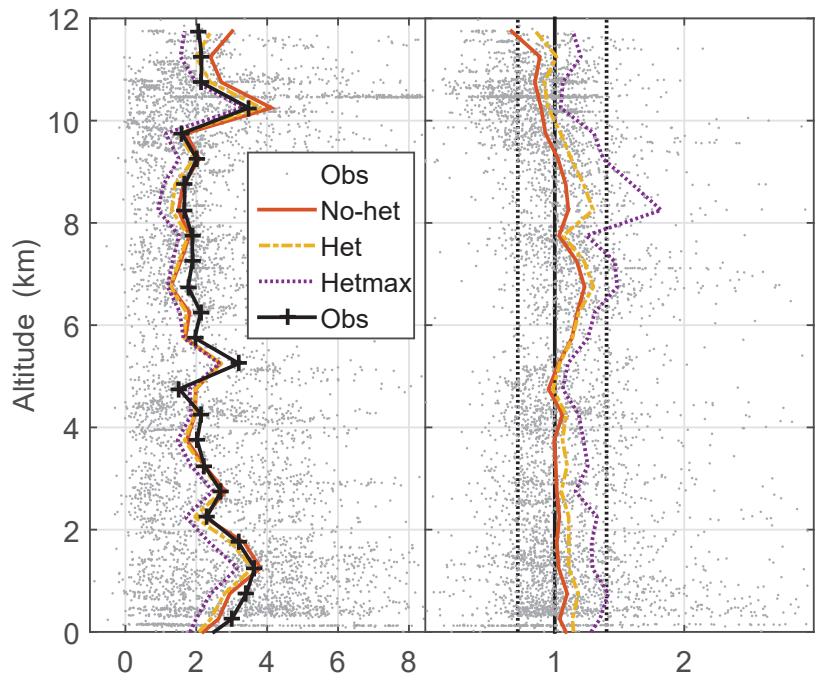

$\begin{array}{ll}\text { (a) } \mathrm{OH}\left(10^{6} \mathrm{~cm}^{-3}\right) & \text { (b) } \mathrm{OH} \mathrm{obs} / \mathrm{mod}\end{array}$

Figure 2. Median measured and modeled $\mathrm{OH}$ as a function of altitude (a); median ratio of observed-to-modeled $\mathrm{OH}$ as a function of altitude (b) for the three models. Gray points are individual $1 \mathrm{~min}$ $\mathrm{OH}$ observations and ratios of observed to no-het-modeled $\mathrm{OH}$. Dotted vertical black lines on the right $(1 / 1.4,1.4)$ are approximate indicators of measurement-model agreement.

estimated combined uncertainties described previously. The statistics from scatter plots using a fitting routine that considered uncertainty in both the observations and the model (York et al., 2004) indicate generally good agreement between observed and modeled $\mathrm{OH}$, with the model explaining $85 \%$ of the $\mathrm{OH}$ variance (Table 2, Fig. S2). 
Table 2. Scatter plot statistics for $\mathrm{OH}$ and $\mathrm{HO}_{2}$.

\begin{tabular}{lllrrrr}
\hline Case & Molecule & Units & Slope & Intercept & $R^{2}$ & Ratio \\
\hline \multirow{2}{*}{ No-het } & $\mathrm{OH}$ & $10^{6} \mathrm{~cm}^{-3}$ & 1.00 & 0.01 & 0.85 & 1.03 \\
& $\mathrm{HO}_{2}$ & pptv & 1.00 & 0.36 & 0.68 & 1.10 \\
\hline \multirow{2}{*}{$\mathrm{Het}$} & $\mathrm{OH}$ & $10^{6} \mathrm{~cm}^{-3}$ & 1.07 & 0.02 & 0.87 & 1.11 \\
& $\mathrm{HO}_{2}$ & pptv & 1.14 & 0.51 & 0.62 & 1.28 \\
\hline \multirow{2}{*}{ Hetmax } & $\mathrm{OH}$ & $10^{6} \mathrm{~cm}^{-3}$ & 1.24 & 0.03 & 0.85 & 1.29 \\
& $\mathrm{HO}_{2}$ & pptv & 1.53 & 0.68 & 0.50 & 1.83 \\
\hline
\end{tabular}

Median observed $\mathrm{HO}_{2}$ was $20-22$ pptv below $2 \mathrm{~km}$ altitude and decreased almost linearly to 3 pptv at $12 \mathrm{~km}$ (Fig. 3). This profile is consistent with the altitude distribution of $\mathrm{HO}_{x}$ sources, which are greater near the surface, and, even with convective uplift of oxygenated chemical species such as $\mathrm{HCHO}$, are still much lower than at the surface. Again, the observed-to-modeled ratio is within the estimated combined uncertainties. In addition, the statistics from scatter plots indicate generally good agreement between observed and modeled $\mathrm{HO}_{2}$, with the model explaining $68 \%$ of the $\mathrm{HO}_{2}$ variance (Table 2, Fig. S2). However, the median observed-tomodeled ratio for the no-het case is 1.3 at $1 \mathrm{~km}$ altitude, decreases to $\sim 1$ at $5 \mathrm{~km}$, and remains near 1 above $5 \mathrm{~km}$. The ratio of the modeled $\mathrm{RO}_{2}$ to $\mathrm{HO}_{2}$ is typically 1 in the $\mathrm{PBL}$ and 0.5 above $5 \mathrm{~km}$. Error in our assumptions for the $\mathrm{RO}_{2}$ interference in the $\mathrm{HO}_{2}$ measurement is a possible cause of the greater observed-to-modeled $\mathrm{HO}_{2}$ below $3 \mathrm{~km}$, but this difference is still well within the combined uncertainty limits.

An indicator of the $\mathrm{HO}_{x}$ cycling between $\mathrm{OH}$ and $\mathrm{HO}_{2}$ is the $\mathrm{HO}_{2} / \mathrm{OH}$ ratio. If the primary $\mathrm{HO}_{x}$ production rate is smaller than the $\mathrm{OH}-\mathrm{HO}_{2}$ cycling rate and there is sufficient $\mathrm{NO}$, the $\mathrm{HO}_{2} / \mathrm{OH}$ ratio approximately equals the $\mathrm{OH}$ loss frequency that cycles $\mathrm{OH}$ into $\mathrm{HO}_{2}$ divided by the reaction frequency of $\mathrm{HO}_{2}$ reactions that cycle $\mathrm{HO}_{2}$ to $\mathrm{OH}$, primarily $\mathrm{HO}_{2}$ reactions with $\mathrm{NO}$ and $\mathrm{O}_{3}$. Both the observed and modeled $\mathrm{HO}_{2} / \mathrm{OH}$ ratios are greater than 100 below $4 \mathrm{~km}$ and fall to less than 10 at $12 \mathrm{~km}$ (Fig. S3). This profile comes from the greater amount of $\mathrm{OH}$ reactants at lower altitudes, which increases the ratio, as opposed to the greater NO amount aloft, which decreases the $\mathrm{HO}_{2} / \mathrm{OH}$ ratio. The observed-tomodeled ratio is within the approximate uncertainty limits ( $1 \sigma$ confidence) of a factor of $1 / 1.4$ to 1.4 .

Another good test of the model photochemistry is the comparison of observed and modeled $\mathrm{OH}$ and $\mathrm{HO}_{2}$ as a function of controlling variables (Fig. 4). The photolysis frequency for $\mathrm{O}_{3}$ producing an excited state $\mathrm{O}$ atom, $J \mathrm{O}\left({ }^{1} \mathrm{D}\right)$, and $\mathrm{O}_{3}$ are both involved in the production of $\mathrm{OH} . \mathrm{O}_{3}$ and $\mathrm{NO}$ cycle $\mathrm{HO}_{2}$ to $\mathrm{OH}$, while modeled $\mathrm{OH}$ reactivity cycles $\mathrm{OH}$ back to $\mathrm{HO}_{2}$. In general, measured and modeled $\mathrm{OH}$ and $\mathrm{HO}_{2}$ agree from $2 \times 10^{-6}$ to $7 \times 10^{-5} \mathrm{~s}^{-1}$ for $J \mathrm{O}\left({ }^{1} \mathrm{D}\right)$, from $2 \times 10^{-3}$ to $7 \times 10^{-1} \mathrm{ppbv}$ for $\mathrm{NO}$, and from 40 to $100 \mathrm{ppbv}$ for $\mathrm{O}_{3}$. For $J \mathrm{O}\left({ }^{1} \mathrm{D}\right)$ greater than $2 \times 10^{-5} \mathrm{~s}^{-1}$, the median observedto-modeled $\mathrm{HO}_{2}$ ratio is 0.98 ; the in-cloud ratio is an in-

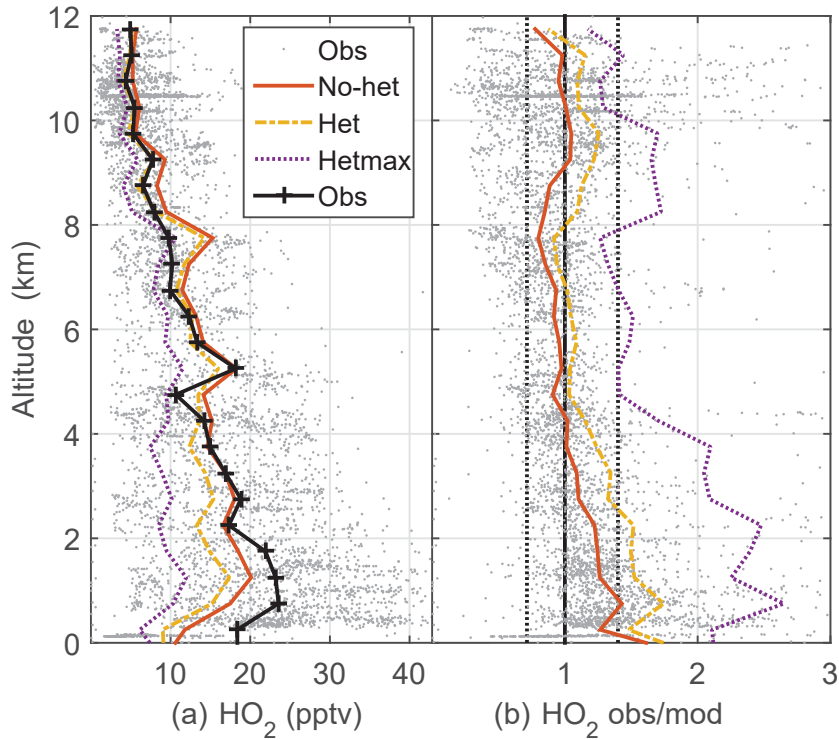

Figure 3. Median measured and modeled $\mathrm{HO}_{2}$ as a function of altitude (a); median ratio of observed-to-modeled $\mathrm{HO}_{2}$ as a function of altitude (b) for the three models. Gray points are individual $1 \mathrm{~min} \mathrm{OH}$ observations and ratios of observed to no-het-modeled $\mathrm{OH}$. Dotted vertical black lines on the right $(1 / 1.4,1.4)$ are approximate indicators of measurement-model agreement.

significant $10 \%$ less than in clear air, indicating that the observed photolysis frequency measurement is accurate even in clouds. The observed-to-modeled $\mathrm{HO}_{2}$ ratio shows little evidence of a NO dependence, although observed-to-modeled $\mathrm{HO}_{2}$ exceeded 2 for $\sim 2 \%$ of the values when $\mathrm{NO}$ was more than 0.5 ppbv. For the $\mathrm{O}_{3}$ observations greater than $200 \mathrm{ppbv}$, which are $0.5 \%$ of all observations, the observed-to-modeled $\mathrm{HO}_{2}$ and $\mathrm{OH}$ were both $\sim 0.5$. It is possible that the behavior as a function of controlling variables is also a function of altitude. However, with the exception of low values of $J \mathrm{O}\left({ }^{1} \mathrm{D}\right)$, the median observed-to-modeled $\mathrm{OH}$ and observedto-modeled $\mathrm{HO}_{2}$ are generally independent of both the controlling variables and altitude (Fig. S4). The observed-tomodeled $\mathrm{OH}$ and $\mathrm{HO}_{2}$ are also independent of whether the measurements were made in Colorado, Texas/Oklahoma, or Alabama (Fig. S5), although the ratios for some altitudes vary widely due to fewer data points in the altitude medians.

\subsection{Comparing $\mathrm{OH}$ reactivity observations with the no-het model}

The measured $\mathrm{OH}$ reactivity was typically 2 to $5 \mathrm{~s}^{-1}$ in the PBL but fell to less than $1 \mathrm{~s}^{-1}$ at $12 \mathrm{~km}$ altitude (Fig. 5). Observed and modeled $\mathrm{OH}$ reactivity is in reasonable agreement when considered in the context of the typical limit of detection for OH reactivity (Fuchs et al., 2017). For DC3, limit of detection for $20 \mathrm{~s}$ measurements is estimated to be about $0.6 \mathrm{~s}^{-1}$, which means that most $\mathrm{OH}$ reactivity measurements 

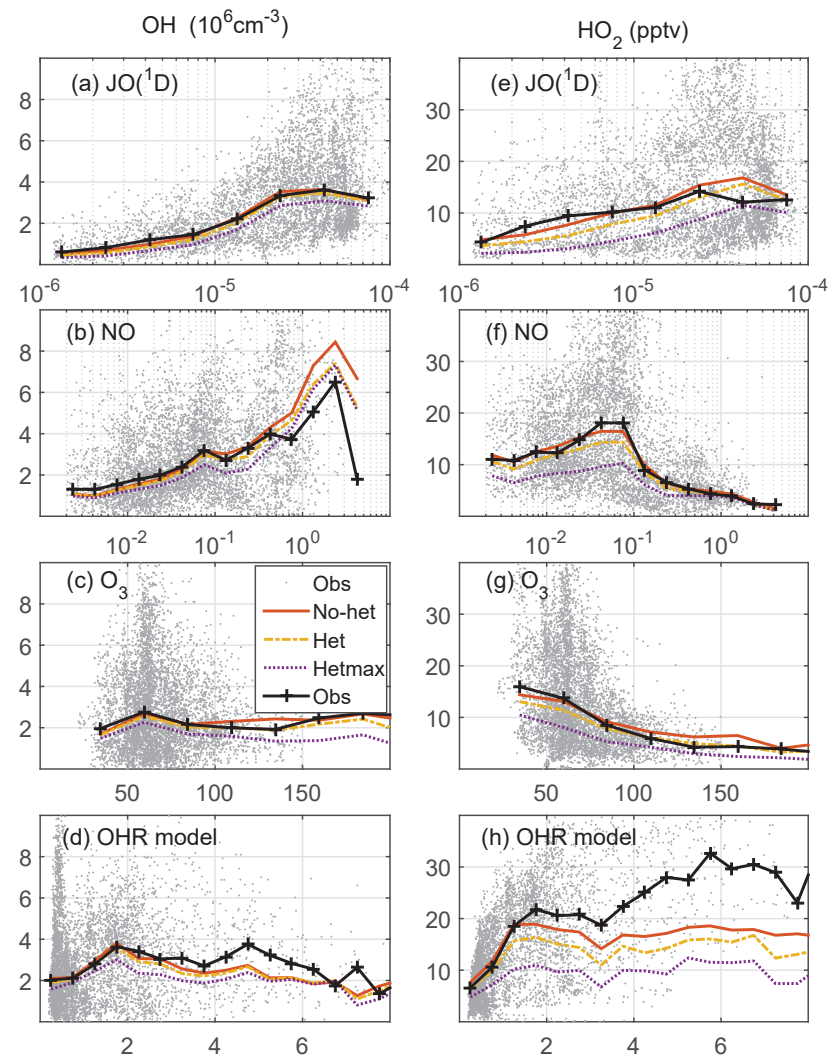

Figure 4. Measured and modeled $\mathrm{OH}(\mathbf{a}, \mathbf{b}, \mathbf{c}, \mathbf{d})$ and $\mathrm{HO}_{2}(\mathbf{e}, \mathbf{f}$, $\mathbf{g}, \mathbf{h})$ as a function of controlling variables: $J \mathrm{O}\left({ }^{1} \mathrm{D}\right)$ in $\mathrm{s}^{-1}$, NO in ppbv, $\mathrm{O}_{3}$ in ppbv, and modeled $\mathrm{OH}$ reactivity in $\mathrm{s}^{-1}$. On the left, $\mathrm{OH}$ is in units of $10^{6} \mathrm{~cm}^{-3}$; on the right, $\mathrm{HO}_{2}$ is in units of pptv.

were at or below the limit of detection. The modeled $\mathrm{OH}$ reactivity for the OHR flow tube temperature and pressure is greater than the modeled $\mathrm{OH}$ reactivity for ambient temperature and pressure by about $0.3 \mathrm{~s}^{-1}$ below $2 \mathrm{~km}$ and by about $0.2 \mathrm{~s}^{-1}$ above $10 \mathrm{~km}$ (Fig. 5). This difference is negligible below $2 \mathrm{~km}$, but grows to a factor of 1.7 at $10 \mathrm{~km}$ where the ambient $\mathrm{OH}$ reactivity is just $0.2-0.3 \mathrm{~s}^{-1}$. For the entire altitude range, the difference between the observed and modeled $\mathrm{OH}$ reactivity is $0.2 \mathrm{~s}^{-1}$ larger for the modeled $\mathrm{OH}$ reactivity at OHR flow tube conditions than for the modeled $\mathrm{OH}$ reactivity at ambient conditions, a difference that is swamped by the noise in the observed $\mathrm{OH}$ reactivity. The median observed $\mathrm{OH}$ reactivity is $1-3 \mathrm{~s}^{-1}$ greater than the modeled $\mathrm{OH}$ reactivity below $3 \mathrm{~km}$, and this difference could be evidence of missing $\mathrm{OH}$ reactivity.

The percent error between the $\mathrm{OH}$ reactivity calculated with modeled $\mathrm{OH}$ reactants and that calculated from only the measured $\mathrm{OH}$ reactants is, on average, less than $4 \%$. In the PBL over Alabama, the $\mathrm{OH}$ reactivity calculated from the model after 1 day of integration was on average $10 \%$ larger than that calculated from the chemical species measurements. In the Colorado and Texas PBL, the average dif-

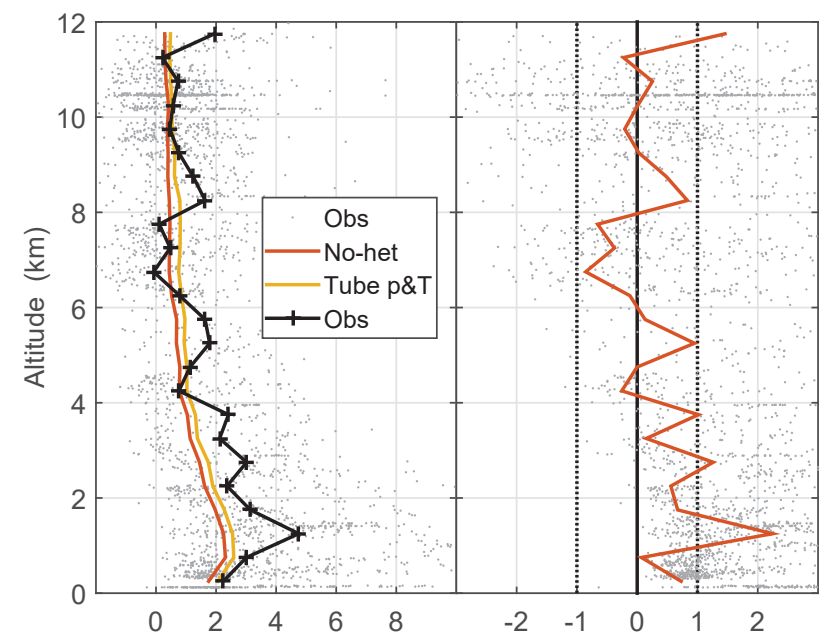

(a) $\operatorname{OHR}\left(\mathrm{s}^{-1}\right)$

(b) $\triangle$ OHR obs-mod

Figure 5. Median observed and model-calculated $\mathrm{OH}$ reactivity (a) and the difference between observed and modeled $\mathrm{OH}$ reactivity (b). The model-calculated $\mathrm{OH}$ reactivity was determined for ambient conditions (no-het) and for the OHR flow tube pressure and temperature (tube $\mathrm{p} \& \mathrm{~T}$ ); see text for explanation. Dotted vertical black lines on the right are approximate indicators of measurementmodel agreement.

ference was less than $4 \%$. According to the model calculations, $\mathrm{CO}$ contributes the most to the $\mathrm{OH}$ reactivity, with $\sim 20 \%$ in the PBL and $30-40 \%$ aloft. Next is $\mathrm{CH}_{4}$ at (5$10) \%$, $\mathrm{HCHO}$ at $(5-10) \%, \mathrm{O}_{3}$ at $(2-10) \%, \mathrm{CH}_{3} \mathrm{CHO}$ at $\sim 5 \%$, and isoprene at (1-2)\%, except in some PBL plumes where it was as much as $60 \%$. The most significant 10 chemical species were all measured and account for (60-70) \% of the total model-calculated $\mathrm{OH}$ reactivity. Thus, for much of $\mathrm{DC} 3$, the $\mathrm{OH}$ reactivity calculated from the DC3 measurements almost completely comprises the measured $\mathrm{OH}$ reactivity.

\subsection{Comparing $\mathrm{OH}$ production and $\mathrm{OH}$ loss}

Another critical test of $\mathrm{OH}$ photochemistry is the balance between $\mathrm{OH}$ production and loss (Fig. 6). The $\mathrm{OH}$ lifetime is typically tenths of a second or less in the PBL and a few seconds at high altitude. Thus, for $1 \mathrm{~min}$ averages, $\mathrm{OH}$ production and loss should essentially be in balance to within the uncertainty estimates from a propagation of error analysis. Modeled $\mathrm{OH}$ production and loss are in balance. These uncertainty estimates were obtained by assuming that $\mathrm{OH}$ production is dominated by $\mathrm{HO}_{2}+\mathrm{NO} \rightarrow \mathrm{OH}+\mathrm{NO}_{2}$ and $\mathrm{O}_{3}$ photolysis followed by reaction of excited state oxygen atoms with water vapor and that the $\mathrm{OH}$ loss is given by the $\mathrm{OH}$ reactivity multiplied by the $\mathrm{OH}$ concentration. The largest contributor to the uncertainty is the zero offset for the $\mathrm{OH}$ reactivity instrument. The observed $\mathrm{OH}$ loss is the observed $\mathrm{OH}$ multiplied by the observed $\mathrm{OH}$ reactiv- 


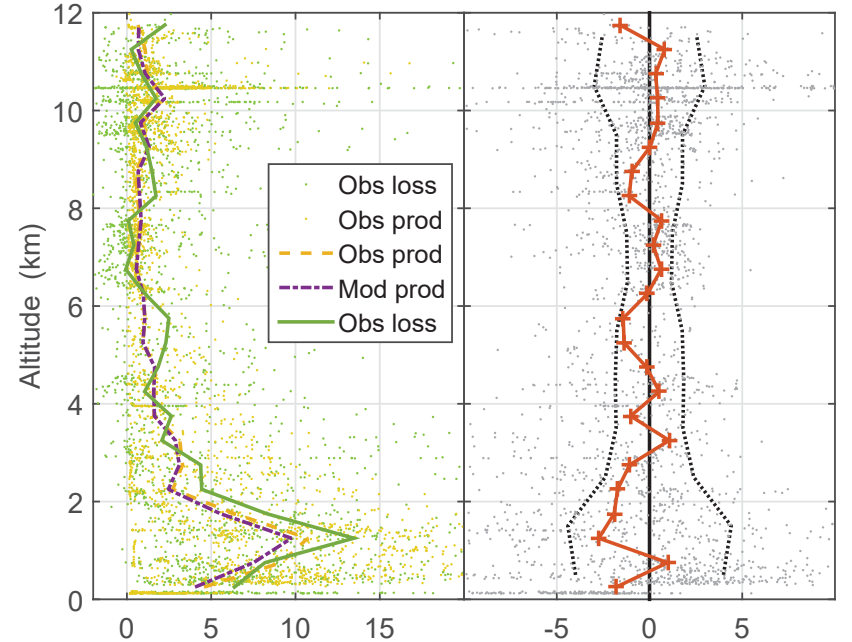

$\begin{array}{ll}\text { (a) OHP \& L }\left(10^{6} \mathrm{~cm}^{-3} \mathrm{~s}^{-1}\right) & \text { (b) } \mathrm{OH}(P-L)\left(10^{6} \mathrm{~cm}^{-3} \mathrm{~s}^{-1}\right)\end{array}$

Figure 6. OH production and loss (a) and difference between measured $\mathrm{OH}$ production and measured $\mathrm{OH}$ loss, $\mathrm{cm}^{-3} \mathrm{~s}^{-1}$ divided (b). Modeled $\mathrm{OH}$ production and loss are equal. Dots are individual 1 min calculations of $\mathrm{OH}$ production using observed atmospheric constituents and photolysis frequencies. Dotted vertical black lines on the right are indicators of $\mathrm{OH}$ production and loss agreement at the $1 \sigma$ confidence level and were determined by a propagation of error analysis.

ity, which was corrected for the difference between ambient and OHR flow tube conditions. While this analysis cannot preclude missing or additional $\mathrm{OH}$ production and loss of $10^{6} \mathrm{~cm}^{-3} \mathrm{~s}^{-1}$ or less, the $\mathrm{OH}$ production and loss, which are calculated mostly from observations, agree to within uncertainties.

\subsection{Comparing $\mathrm{HO}_{x}$ observations with models containing heterogeneous chemistry}

Ample aerosol and ice during DC3 provide tests for possible effects of heterogeneous chemistry on $\mathrm{OH}$ and $\mathrm{HO}_{2}$. We look first at the impact that adding heterogeneous chemistry (het, $\alpha_{\text {ice }}=1.0 ; \alpha_{\text {aer }}=0.2$ ), and maximum heterogeneous chemistry (hetmax, $\alpha_{\text {ice }}=1.0 ; \alpha_{\text {aer }}=1.0$ ) to the model has on the comparison of median observed and modeled $\mathrm{OH}$ and $\mathrm{HO}_{2}$.

In Figs. 2-4 and S6-S7 and Tables 2 and S1, the no-het and het models agree with the observed $\mathrm{OH}$ and $\mathrm{HO}_{2}$ to within the combined uncertainties, with the exception of the het model for $\mathrm{HO}_{2}$ when the aerosol surface area per $\mathrm{cm}^{-3}$ of air was greater than $10^{-6} \mathrm{~cm}^{2} \mathrm{~cm}^{-3}$. In that case, the ratio of the observed-to-modeled $\mathrm{HO}_{2}$ was too large, indicating that the het model was reducing $\mathrm{HO}_{2}$ too much. On the other hand, the difference between the observations and hetmax model is greater than the uncertainty limits in almost every comparison. When the $\mathrm{OH}$ observed-to-modeled ratio is plotted as a function of aerosol surface area (Fig. 7), the no-het model gives a better agreement with the observations as a function

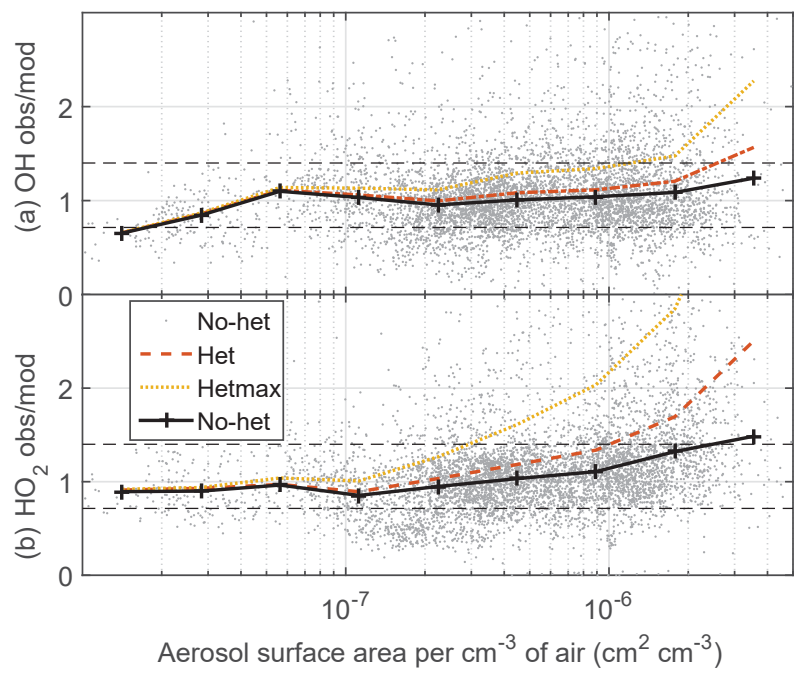

Figure 7. Median observed-to-modeled $\mathrm{OH}$ (a) and $\mathrm{HO}_{2}$ (b) versus aerosol surface area per $\mathrm{cm}^{-3}$ of air. Dotted horizontal black lines are approximate indicators of measurement-model agreement.

of surface area than the het model does. For $\mathrm{HO}_{2}$, the difference between the het model and the observations exceeds the combined uncertainty limits when the aerosol surface area per $\mathrm{cm}^{-3}$ of air exceeds $10^{-6} \mathrm{~cm}^{2} \mathrm{~cm}^{-3}$.

For heterogeneous uptake on ice, the observed-to-modeled comparisons of $\mathrm{OH}$ and $\mathrm{HO}_{2}$ are roughly independent of ice surface area (Fig. S8). Comparing the model with $\mathrm{HO}_{2}$ uptake on ice equalling 1 to a model with $\mathrm{HO}_{2}$ uptake on ice set to 0 decreases $\mathrm{OH}$ and $\mathrm{HO}_{2}$ by only $10 \%$ for the largest ice surface area per $\mathrm{cm}^{-3}$ of air of $7 \times 10^{-5} \mathrm{~cm}^{2} \mathrm{~cm}^{-3}$. $\mathrm{HO}_{2}$ uptake on ice causes at most a few percent decrease in $\mathrm{HO}_{2}$.

The addition of $\mathrm{RO}_{2}$ heterogeneous chemistry on aerosol and ice did reduce the modeled $\mathrm{RO}_{2}$ by $10 \%$ on average for the het model, but did not reduce either $\mathrm{OH}$ or $\mathrm{HO}_{2}$ by more than $1 \%$ on average. Including $\mathrm{RO}_{2}$ uptake along with $\mathrm{OH}$ and $\mathrm{HO}_{2}$ uptake had only a small impact on the heterogeneous effects on $\mathrm{OH}$ and $\mathrm{HO}_{2}$.

\subsection{Evolution of $\mathrm{OH}$ and $\mathrm{HO}_{2}$ downwind of a nighttime mesoscale convective system}

The quasi-Lagrangian tracking of convective outflow on 21 June provided an opportunity to test the photochemical evolution of $\mathrm{OH}$ and $\mathrm{HO}_{2}$ on the morning of 21 June. The flight legs perpendicular to the wind were approximately advected downwind. Initially, observed and modeled $\mathrm{OH}$ and $\mathrm{HO}_{2}$ were close to 0 (Fig. 8). However, both modeled $\mathrm{OH}$ and $\mathrm{HO}_{2}$ soon grew to exceed measured $\mathrm{OH}$ and $\mathrm{HO}_{2}$ by about $20 \%-50 \%$ until about 08:00 CST. For the remainder of the flight, observed and modeled $\mathrm{OH}$ are in substantial agreement for all three models, which are essentially identical except between 09:30 and 11:00 CST when the aerosol surface area per $\mathrm{cm}^{-3}$ of air was the greatest. For $\mathrm{HO}_{2}$, observed 


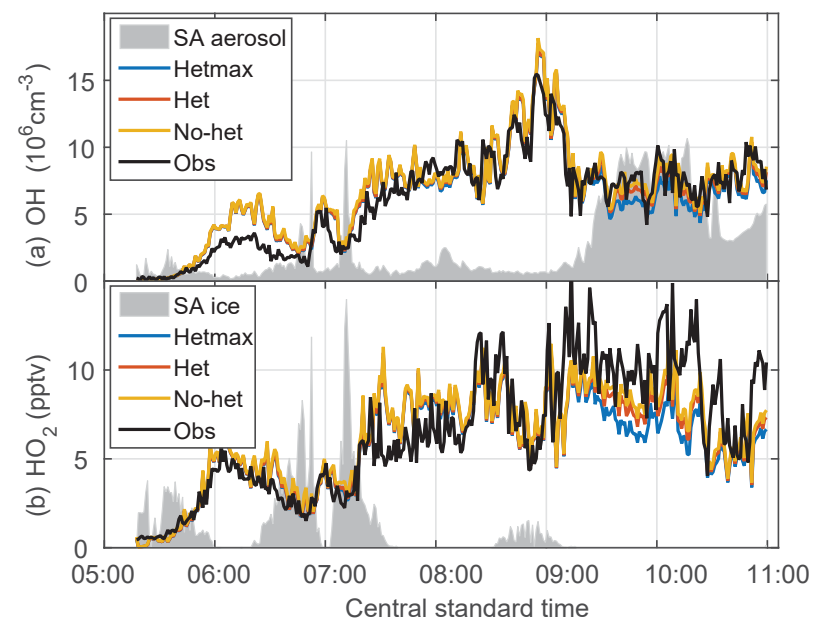

Figure 8. Evolution of $\mathrm{OH}$ (a) and $\mathrm{HO}_{2}$ (b) downwind of a MCS. The het and hetmax models are essentially identical to the no-het model for this flight except in heavy aerosol amounts from 9:00 to 11:00 CST. The gray shading is scaled aerosol surface area (a) and is scaled ice surface area (b).

$\mathrm{HO}_{2}$ exceeds modeled by a factor of $\sim 1.5$ after 09:00 CST. In this time period, the observations agree best with the nohet and het models. Thus, the basic observed behavior of $\mathrm{OH}$ and $\mathrm{HO}_{2}$ is captured by the no-het and het models although there is quantitative disagreement between the model and observations of $\mathrm{OH}$ and $\mathrm{HO}_{2}$ for local solar time between 05:45 and 08:15 CST and of $\mathrm{HO}_{2}$ after 09:00 CST.

Even though more than half of the first three legs were in an ice cloud, the scaled surface area for aerosol particles (Fig. 8a) and ice (Fig. 8b) does not correlate with the differences between observed and modeled $\mathrm{OH}$ and $\mathrm{HO}_{2}$.

As a test of the photochemistry, $\mathrm{OH}$ can be calculated from the observed decay of $\mathrm{OH}$ reactants. Nault et al. (2016) showed that the observed decay of ethane, ethyne, and toluene was consistent with an average observed $\mathrm{OH}$ of $9.5 \times$ $10^{6} \mathrm{~cm}^{-3}$ for times from 07:35 to 09:50 CST. An ATHOS recalibration since the publication of Nault et al. (2016) brings the mean observed number for this time interval down to $8.8 \times 10^{6} \mathrm{~cm}^{-3}$. This recalibration was needed to account for the window absorption of calibrated $185 \mathrm{~nm}$ radiation that was neglected in the initial DC3 calibration. This median revised observed $\mathrm{OH}$ concentration is consistent with the mean modeled $\mathrm{OH}$ concentration of $9.6 \times 10^{6} \mathrm{~cm}^{-3}$. These results agree well within uncertainties and support the observed $\mathrm{OH}$.

Another good test of the photochemistry is a comparison between the observed $\mathrm{O}_{3}$ change and the accumulated calculated $\mathrm{O}_{3}$ production rate (Fig. 9). The $\mathrm{O}_{3}$ change is actually slightly larger than the observed $\mathrm{O}_{3}$ because some of the new $\mathrm{O}_{3}$ is partitioned into $\mathrm{NO}_{2}$, so that the quantity of interest is the change in $\mathrm{O}_{3}$ plus the change in $\mathrm{NO}_{2}$. The ozone production rate, $P\left(\mathrm{O}_{3}\right)$, can be calculated with Eq. (3).

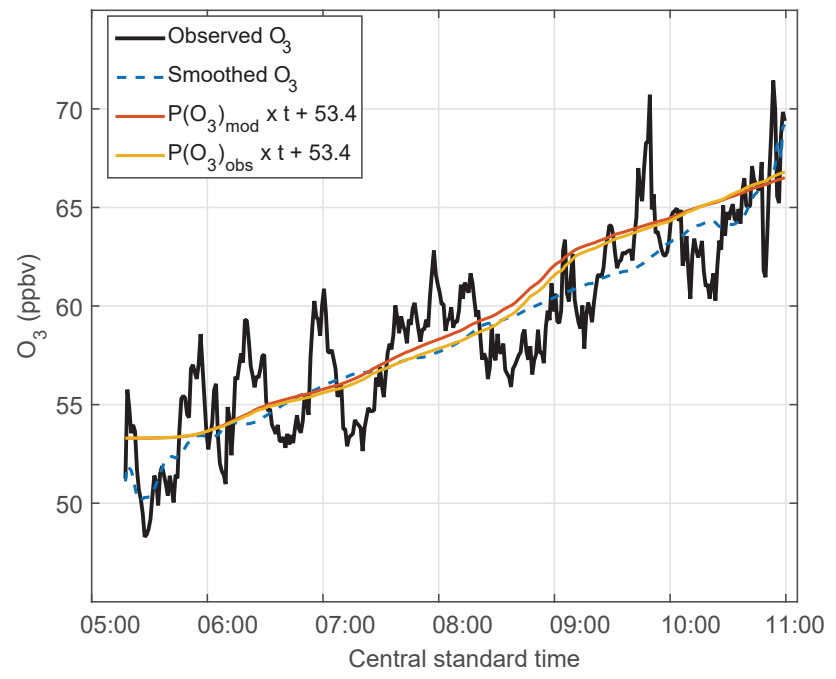

Figure 9. The $\mathrm{O}_{3}$ trend in MCS outflow. Observed $\mathrm{O}_{3}-1$ min data (black line) and smoothed data (dashed blue line, 180 min filter) shows variability along the legs set perpendicular to the air flow and also shows the $\mathrm{O}_{3}$ trend with time. The calculated $\mathrm{O}_{3}$ uses the accumulated calculated $\mathrm{O}_{3}$ production rates $\left(P\left(\mathrm{O}_{3}\right) \times\right.$ time $)$ for observed (yellow) and modeled $\mathrm{HO}_{2}$ (red) and adds those values to an initial value of $53.4 \mathrm{ppbv}$ to show the calculated $\mathrm{O}_{3}$ trend.

$$
\begin{aligned}
P\left(\mathrm{O}_{3}\right)= & k k_{\mathrm{NO}+\mathrm{HO}_{2}}[\mathrm{NO}]\left[\mathrm{HO}_{2}\right] \\
& +\sum_{i} k_{\mathrm{NO}+\mathrm{RO}_{2 \mathrm{i}}}[\mathrm{NO}]\left[\mathrm{RO}_{2 \mathrm{i}}\right]-L\left(\mathrm{O}_{3}\right)
\end{aligned}
$$

$k$ is a reaction rate coefficient and $L\left(\mathrm{O}_{3}\right)$ is the loss term for ozone. In this case, the loss term was only a few tenths ppbv $\mathrm{h}^{-1}$ (Fig. S9) and can be neglected. These rates are calculated in ppbv $\mathrm{min}^{-1}$ and then accumulated at times from $05: 45$ to $11: 15 \mathrm{CST}$, in order to match the time period over which the DC-8 was sampling the MCS plume. This accumulated ozone production was calculated for the observed $\mathrm{HO}_{2}$ plus modeled $\mathrm{RO}_{2}$ and for the modeled $\mathrm{HO}_{2}$ plus modeled $\mathrm{RO}_{2}$. Modeled $\mathrm{RO}_{2}$ is primarily $\mathrm{CH}_{3} \mathrm{O}_{2}$ and $\mathrm{CH}_{3} \mathrm{CH}_{2} \mathrm{O}_{2}$ and its mixing ratio is half the $\mathrm{HO}_{2}$ mixing ratio above $5 \mathrm{~km}$. $\mathrm{HO}_{2}$ accounts for a little more than half the total $\mathrm{O}_{3}$ production. In order to compare the observed $\mathrm{O}_{3}$ change to that accumulated from calculated $\mathrm{O}_{3}$ production, an ozone offset of $53.4 \mathrm{ppbv}$ was added to the accumulated $\mathrm{O}_{3}$ production at 06:00 CST, which is when the ozone production commenced.

Ozone varied by $5-7 \mathrm{ppbv}$ over the legs and was higher on one end of the leg than the other. These variations are smoothed using a $180 \mathrm{~min}$ filter. During the $5 \mathrm{~h}$ from 06:00 to 11:00 CST, the observed $\mathrm{O}_{3}$ change was $14 \mathrm{ppbv}$, although 2 ppbv of that change were in the final few minutes of observation. For the same time period, the ozone production calculated from modeled $\mathrm{HO}_{2}$ and modeled $\mathrm{RO}_{2}$ was $13 \mathrm{ppbv}$, and the ozone production calculated from observed $\mathrm{HO}_{2}$ and modeled $\mathrm{RO}_{2}$ was 13 ppbv. These three methods for deter- 
mining $\mathrm{O}_{3}$ production agree to well within their uncertainties and provide additional confirmation of the observed and modeled $\mathrm{HO}_{2}$ and the modeled $\mathrm{RO}_{2}$.

\section{Discussion}

These comparisons between median observed and modeled $\mathrm{OH}, \mathrm{HO}_{2}$, and $\mathrm{OH}$ reactivity display an agreement that is generally within the combined uncertainties of the observations and model. This agreement within uncertainties generally holds in scatter plots and associated statistics and as a function of altitude, $J \mathrm{O}\left({ }^{1} \mathrm{D}\right), \mathrm{NO}, \mathrm{O}_{3}$, and the modeled $\mathrm{OH}$ reactivity. It also holds for the wide range of environments encountered during DC3, which includes different altitudes, cloudiness, and sunlight over roughly one-third of the continental United States.

A closer look at the figures shows seemingly random differences between observed and modeled $\mathrm{OH}$ and $\mathrm{HO}_{2}$. While most observed and modeled $\mathrm{OH}, \mathrm{HO}_{2}$, and $\mathrm{OH}$ reactivity 1 min data are within the combined uncertainties ( $1 \sigma$ confidence) of each other (57\%), there are sometimes persistent unexplained differences (Fig. S1). An example is from the 21 June flight over Missouri and Illinois (Fig. 8). For both $\mathrm{OH}$ and $\mathrm{HO}_{2}$, there are times when the modeled $\mathrm{OH}$ and $\mathrm{HO}_{2}$ are higher than the measurements, lower than the measurements, and equal to the measurements. At the same time, the measured $\mathrm{OH}$ reactivity is sometimes greater than the modeled $\mathrm{OH}$ reactivity and sometimes equal to it. These types of discrepancies are proving to be hard to resolve. A simple correlation analysis found no strong correlation between the observed-to-modeled ratio or difference and any model output variable. Employing more sophisticated methods in future work may be more productive.

\subsection{Comparing DC3 to previous studies}

All previous aircraft studies that included measurements of $\mathrm{OH}$ and $\mathrm{HO}_{2}$ have compared these observations to calculations from constrained photochemical box models. There is uncertainty in comparing the results from one study to another because often the instruments, their calibrations, and models are different or have evolved over time. Comparing results from very different environments amplifies this problem. As a result, the comparisons here are restricted to previous studies in air that was heavily influenced by convection.

$\mathrm{NO}, \mathrm{CO}, \mathrm{O}_{3}$, and $\mathrm{JO}\left({ }^{1} \mathrm{D}\right)$ from $\mathrm{DC} 3$ are remarkably similar to those observed in the Intercontinental Chemical Transport Experiment - North America Phase A (INTEX-A) in 2004 during flights over the central and eastern US (Ren et al., 2008) and to those observed from only 7 to $10 \mathrm{~km}$ for HOOVER 2 in summer 2007 during flights over central Europe (Regelin et al., 2013). As in DC3, observed and modeled $\mathrm{OH}$ agree to within uncertainties for INTEX-A and HOOVER 2 over their altitude ranges. On the other hand, observed and modeled $\mathrm{HO}_{2}$ agree to within uncertainties for DC3, HOOVER 2, and INTEX-A up to $8 \mathrm{~km}$, but then observed $\mathrm{HO}_{2}$ grows to exceed modeled $\mathrm{HO}_{2}$ by a factor of 3 at $11 \mathrm{~km}$ for INTEX-A, in contrast to both DC3 and HOOVER 2 where observed and modeled $\mathrm{HO}_{2}$ agree to within the combined uncertainties.

One explanation for the $\mathrm{HO}_{2}$ discrepancy in INTEX-A could be the treatment of the $\mathrm{HO}_{2} \mathrm{NO}_{2}$ formation rate in the model. MCMv3.3.1 uses a reaction rate coefficient that takes the much lower low-temperature reaction rate coefficient of the laboratory study of Bacak et al. (2011) into account, while the Jet Propulsion Laboratory (JPL) evaluation (Burkholder et al., 2015) does not. For DC3, using the $\mathrm{MCMv3.3.1} \mathrm{rate} \mathrm{coefficient,} \mathrm{observed-to-modeled} \mathrm{OH}$ and $\mathrm{HO}_{2}$ are $0.85-0.9$ at altitudes above $10 \mathrm{~km}$ altitude, and modeled $\mathrm{HO}_{2} \mathrm{NO}_{2}$ is 1.9 times measured, but if the JPL recommended rate is used, then modeled $\mathrm{OH}$ and $\mathrm{HO}_{2}$ both increase by a factor of 1.5 at altitudes above $10 \mathrm{~km}$, shifting the observed-to-modeled ratios to 1.3-1.4, while increasing modeled $\mathrm{HO}_{2} \mathrm{NO}_{2}$ to $5-10$ times that observed (Fig. S10). The JPL-recommended reaction rate coefficient was used in the model for INTEX-A, which could explain some of the difference with DC3, except that the observed-to-modeled $\mathrm{OH}$ ratio should also be a factor of 3 for INTEX-A.

For DC3, observed and modeled $\mathrm{HO}_{2}$ appear to agree as a function of $\mathrm{NO}$ up to about $3 \mathrm{ppbv}$, which are the highest NO values encountered. For several previous ground-based studies, the observed $\mathrm{HO}_{2}$ was not obviously greater than the modeled $\mathrm{HO}_{2}$ until $\mathrm{NO}$ reached $\sim 2$ ppbv or greater (Martinez et al., 2003; Ren et al., 2003; Shirley et al., 2006; Kanaya et al., 2007; Brune et al., 2016). For aircraft studies, in some cases, the observed $\mathrm{HO}_{2}$ did not obviously exceed the modeled $\mathrm{HO}_{2}$ until $\mathrm{NO}$ approached 2 ppbv (Baier et al., 2017), while in other studies, the obvious exceedance occurred when NO was only a few hundred pptv (Faloona et al., 2000; Ren et al., 2008). Olson et al. (2006) showed that the Faloona et al. (1999) results for the SUCCESS campaign (central US, 1996) could be explained by the averaging of sharp plumes containing high $\mathrm{NO}$ and depleted $\mathrm{HO}_{2}$ with the surrounding air. They showed that the SONEX (North Atlantic, 1997) results could be mostly explained by including all observed $\mathrm{HO}_{x}$ precursors and updated kinetic rate coefficients and photolysis frequencies in the model. For INTEXA (Ren et al., 2008), the enhanced NO is in the upper troposphere, where the observed-to-modeled $\mathrm{HO}_{2}$ reached a factor of 3. It is possible that the $\mathrm{HO}_{2}$ calibration was in error at low pressure (i.e., higher altitudes), although observed and modeled $\mathrm{HO}_{2}$ agree in the stratosphere. It is also possible that there were missing $\mathrm{HO}_{2}$ sources or outdated reaction rates in the model chemistry. We intend to re-examine INTEX-A and other previous NASA DC-8 missions that included ATHOS to see if an updated model can better simulate these $\mathrm{HO}_{2}$ observations.

The production rates of $\mathrm{HO}_{x}$ (Fig. S11) and $\mathrm{O}_{3}$ (Fig. S9) are comparable to those found in previous studies (Ren et 
al., 2008; Olson et al., 2012). Modeled $\mathrm{HO}_{x}$ production is dominated by $\mathrm{O}_{3}$ photolysis below $8 \mathrm{~km}$, as has been previously observed (Regelin et al., 2013), but HCHO photolysis dominates above $10 \mathrm{~km} . \mathrm{HO}_{x}$ production by HONO photolysis essentially balances $\mathrm{HO}_{x}$ loss by HONO formation. The calculated $\mathrm{O}_{3}$ production rates are also comparable to these other studies, which find production rates of a few ppbv $\mathrm{h}^{-1}$ in the PBL and above $10 \mathrm{~km}$ with a small loss at mid-altitude (Fig. S9). A spike in excess of $5 \mathrm{ppbv} \mathrm{h}^{-1}$ was found in a fire plume on 22 June (day of year 174), where abundances of both VOCs and $\mathrm{NO}_{x}$ were enhanced.

\subsection{Effects of heterogeneous chemistry on $\mathrm{OH}$ and $\mathrm{HO}_{2}$}

These DC3 results indicate that a total uptake coefficient is much lower than 1 for aerosol. They also suggest that a total uptake coefficient of 0.2 is probably also too high because the model calculates $\mathrm{HO}_{2}$ values that are much lower than observed $\mathrm{HO}_{2}$ when the aerosol surface area per $\mathrm{cm}^{-3}$ of air was greater than $10^{-6} \mathrm{~cm}^{2} \mathrm{~cm}^{-3}$. In the DC3 environment, $\mathrm{HO}_{x}$ has substantial gas-phase loss pathways, making it difficult for heterogeneous chemistry to be dominant when the model uses an uptake coefficient consistent with laboratory studies, except at the largest aerosol surface area per $\mathrm{cm}^{-3}$ of air. For the het case with a total uptake coefficient of 0.2 , $\mathrm{HO}_{x}$ loss including heterogeneous loss is 1.4 times the gasphase-only loss when the aerosol surface area per $\mathrm{cm}^{-3}$ of air is $5 \times 10^{-7} \mathrm{~cm}^{2} \mathrm{~cm}^{-3}$, but grows to 1.5 at $1 \times 10^{-6} \mathrm{~cm}^{2} \mathrm{~cm}^{-3}$ and 2.5 for the few $1 \mathrm{~min}$ data points when it is greater than $3 \times 10^{-6} \mathrm{~cm}^{2} \mathrm{~cm}^{-3}$. This increase in $\mathrm{HO}_{x}$ loss translates into decrease in the modeled $\mathrm{HO}_{x}$, with the decrease changing roughly as the square root of the increase in the $\mathrm{HO}_{x}$ loss.

In DC3, the DC-8 spent hours flying in anvils of the cumulus clouds, which consisted of ice particles. DC3 provides evidence that the $\mathrm{HO}_{2}$ uptake on ice is small. These results are consistent with $\mathrm{HO}_{2}$ results over the western Pacific Ocean (Olson et al., 2004) but not with those over the northern Atlantic (Jeaglé et al., 2000). In Mauldin III et al. (1998), a large difference between the observed and modeled $\mathrm{OH}$ was found in clouds, but this difference may have been due to the lack of photolysis frequency measurements, which are crucial to test photochemistry in a cloudy environment. In DC3, the DC-8 spent essentially no time in liquid clouds, for which there is evidence of measurable $\mathrm{HO}_{2}$ uptake (Olson et al., 2006; Commane et al., 2010; Whalley et al., 2015). Thus, these DC3 results provide constraints of $\mathrm{HO}_{2}$ uptake on aerosol and ice particles, but not on liquid water particles.

In other cleaner environments or dirtier environments with a large amount of high aerosol surface area per $\mathrm{cm}^{-3}$ of air, heterogeneous chemistry can be a substantial fraction of the entire $\mathrm{HO}_{x}$ loss and thus affect $\mathrm{HO}_{2}$ and $\mathrm{OH}$ abundances. Measuring $\mathrm{OH}$ and $\mathrm{HO}_{2}$ in these environments will provide a better test of the understanding of $\mathrm{HO}_{2}$ heterogeneous chemistry on aerosol particles than DC3 did.

\section{Conclusions}

The general agreement between the observed and modeled $\mathrm{OH}$ and $\mathrm{HO}_{2}$ for the complex DC3 environment is encouraging. It suggests that a photochemical box model can simulate the observed $\mathrm{OH}$ and $\mathrm{HO}_{2}$ to well within combined uncertainties, if properly constrained with measurements of other chemical species, photolysis frequencies, and environmental conditions. On the other hand, it is difficult to explain the unexpected deviations between observed and modeled $\mathrm{OH}$ and $\mathrm{HO}_{2}$, such as is observed in Figs. 8 or S1. Neither heterogeneous chemistry nor organic peroxyl chemistry are able to explain these deviations.

There are other possible causes for these discrepancies. First, it can be difficult to maintain instrument calibrations for not only $\mathrm{OH}$ and $\mathrm{HO}_{2}$ but also for all the other measurements that were used to constrain the model to calculate $\mathrm{OH}$ and $\mathrm{HO}_{2}$. Second, the simultaneous measurements need to be properly conditioned so that they can be used as model constraints. This process includes filling in isolated missing values because, if this was not done, the constraining data set would be sparse. For DC3, using the merged data set with no interpolation is less than $10 \%$ of the full data set, but the observed and modeled $\mathrm{OH}$ and $\mathrm{HO}_{2}$ have essentially the same relationships as with the interpolated data set (Table S21). Third, the model parameters, such as integration times and decay times, must be set up so that the model calculations represent the observations and their variations. Varying these times caused a range of modeled values that was far smaller than the large observed-to-modeled differences, as seen in Fig. S1. For DC3, the 1 min data are adequate for the timescale of variations for most cases, except in small fire plumes and some spikes in lightning $\mathrm{NO}_{x}$ in the anvil. Fourth, multiple methods are needed to determine if differences between observations and model are significant. For DC3, the comparisons between observations and models are robust despite the method of comparison. Thus, none of these appear to be the cause of the unexplained deviations between observed and modeled $\mathrm{OH}$ and $\mathrm{HO}_{2}$. A more thorough model uncertainty and sensitivity analysis could unveil the cause.

Even with these observed-to-modeled discrepancies, the general agreement for observed and modeled $\mathrm{OH}$ and $\mathrm{HO}_{2}$ suggests that current photochemical models can simulate observed atmospheric oxidation processes even around clouds to within these combined uncertainties. Reducing these uncertainties will enable comparisons of observed and modeled $\mathrm{OH}$, and $\mathrm{HO}_{2}$ to provide a more stringent test of the understanding of atmospheric oxidation chemistry and thus to lead to an improvement in that understanding.

Code availability. The Matlab code used for the zero-dimensional photochemical box modeling with the MCMv3.3.1 mechanism can 
be downloaded from Wolfe (2017). The paper describing this model is Wolfe et al. (2016).

Data availability. The merge file for the DC3 DC- 8 data and the updated $\mathrm{OH}, \mathrm{HO}_{2}$, and $\mathrm{OH}$ reactivity numbers can be accessed by DOI: https://doi.org/10.5067/Aircraft/DC3/DC8/Aerosol-TraceGas (Aknan and Chen, 2017).

Supplement. The supplement related to this article is available online at: https://doi.org/10.5194/acp-18-14493-2018-supplement.

Author contributions. WHB, XR, LZ, JM, DOM, BEA, DRB, RCC, GSD, SRH, TFH, LGH, BAN, JP, IP, TBR, TS, AS, KU, AW, and PJW made the DC3 measurements that are critical for the modeling and comparison of modeled and measured $\mathrm{OH}$ and $\mathrm{HO}_{2}$ in this paper. WB performed the modeling, did the analysis, wrote the manuscript, and made edits provided by the co-authors before submitting the manuscript.

Competing interests. The authors declare that they have no conflict of interest.

Acknowledgements. The Deep Convective Clouds and Chemistry (DC3) experiment is sponsored by the U.S. National Science Foundation (NSF), the National Aeronautics and Space Administration (NASA), the National Oceanic and Atmospheric Administration (NOAA), and the Deutsches Zentrum für Luft- und Raumfahrt (DLR). Data provided by NCAR/EOL are supported by the National Science Foundation. Acetone/propanal measurements aboard the DC- 8 during DC3 were supported by the Austrian Federal Ministry for Transport, Innovation, and Technology (BMVIT) through the Austrian Space Applications Programme (ASAP) of the Austrian Research Promotion Agency (FFG). Support for ATHOS and OHR measurements aboard the NASA DC-8 during DC3 comes from NASA grant NNX12AB84G. We thank NASA management, pilots, and operations personnel for the opportunity to gather these observations; the people of Salina, KS, for hosting us and providing excellent facilities; Glenn Wolfe for his publicly available F0AM model framework; and the University of Leeds for the publicly available MCMv3.3.1 photochemical model. We also thank Joel Thornton for his insights into $\mathrm{HO}_{2}$ heterogeneous chemistry, and Paul Lawson, Paul Wennberg, John Crounse, and Jason. St. Clair for the use of their measurements.

Edited by: Dwayne Heard

Reviewed by: two anonymous referees

\section{References}

Aknan, A. and Chen, G.: NASA LaRC Airborne Science Data for Atmospheric Composition - DC3,
https://doi.org/10.5067/Aircraft/DC3/DC8/Aerosol-TraceGas, 2017.

Apel, E. C., Olson, J. R., Crawford, J. H., Hornbrook, R. S., Hills, A. J., Cantrell, C. A., Emmons, L. K., Knapp, D. J., Hall, S., Mauldin III, R. L., Weinheimer, A. J., Fried, A., Blake, D. R., Crounse, J. D., Clair, J. M. St., Wennberg, P. O., Diskin, G. S., Fuelberg, H. E., Wisthaler, A., Mikoviny, T., Brune, W., and Riemer, D. D.: Impact of the deep convection of isoprene and other reactive trace species on radicals and ozone in the upper troposphere, Atmos. Chem. Phys., 12, 1135-1150, https://doi.org/10.5194/acp-12-1135-2012, 2012.

Apel, E. C., Hornbrook, R. S., Hills, A. J., Blake, N. J., Barth, M. C., Weinheimer, A., Cantrell, C., Rutledge, S. A., Basarab, B., Crawford, J., Diskin, G., Homeyer, C. R., Campos, T., Flocke, F., Fried, A., Blake, D. R., Brune, W., Pollack, I., Peischl, J. Ryerson, T., Wennberg, P. O., Crounse, J. D., Wisthaler, A., Mikoviny, T., Huey, G., Heikes, B., O'Sullivan, D., and Riemer, D. D.: Upper tropospheric ozone production from lightning $\mathrm{NO}_{\mathrm{x}}$-impacted convection: Smoke ingestion case study from the DC3 campaign. J. Geophys. Res. Atmos., 120, 2505-2523, 2015.

Assaf, E., Sheps, L., Whalley, L., Heard, D., Tomas, A., Schoemaecker, C., and Fittschen, C.: The Reaction between $\mathrm{CH}_{3} \mathrm{O}_{2}$ and $\mathrm{OH}$ Radicals: Product Yields and Atmospheric Implications, Environ. Sci. Technol., 51, 2170-2177, https://doi.org/10.1021/acs.est.6b06265, 2017.

Bacak, A., Cooke, M. C., Bardwell, M. W., McGillen, M. R., Archibald, A. T., Huey, L. G., Tanner, D., Utembe, S. R., Jenkin, M. E., Derwent, R. G., Shallcross, D. E., and Percival, C. .: Kinetics of the $\mathrm{HO}_{2}+\mathrm{NO}_{2}$ Reaction: On the Impact of New GasPhase Kinetic Data for the Formation of $\mathrm{HO}_{2} \mathrm{NO}_{2}$ on $\mathrm{HO}_{x}, \mathrm{NO}_{x}$ and $\mathrm{HO}_{2} \mathrm{NO}_{2}$ Levels in the Troposphere, Atmos. Environ., 45, 6414-6422, 2011.

Baier, B. C., Brune, W. H., Miller, D. O., Blake, D., Long, R., Wisthaler, A., Cantrell, C., Fried, A., Heikes, B., Brown, S., McDuffie, E., Flocke, F., Apel, E., Kaser, L., and Weinheimer, A.: Higher measured than modeled ozone production at increased $\mathrm{NO}_{x}$ levels in the Colorado Front Range, Atmos. Chem. Phys., 17, 11273-11292, https://doi.org/10.5194/acp-17-112732017, 2017.

Barth, M. C., Cantrell, C. A., Brune, W. H., Rutledge, S. A., Crawford, J. H., Huntrieser, H., Carey, L. D., MacGorman, D., Weisman, M., Pickering, K. E., Bruning, E., Anderson, B., Apel, E., Biggerstaff, M., Campos, T., Campuzano-Jost, P. Cohen, R., Crounse, J., Day, D. A., Diskin, G., Flocke, F., Fried, A., Garland, C., Heikes, B., Honomichl, S., Hornbrook, R., Huey, L. G., Jimenez, J. L., Lang, T., Lichtenstern, M., Mikoviny, T., Nault, B., O’Sullivan, D., Pan, L. L., Peischl, J., Pollack, I., Richter, D., Riemer, D., Ryerson, T., Schlager, H., St Clair, J., Walega, J., Weibring, P., Weinheimer, A., Wennberg, P., Wisthaler, A., Wooldridge, P. J., and Ziegler, C.: The Deep Convective Clouds and Chemsitry (DC3) Field Campaign, B. Am. Meteorol. Soc., 96, 1281-1309, 2015.

Barth, M. C., Bela, M. M., Fried, A., Wennberg, P. O., Crounse, J. D., St Clair, J. M., Blake, N. J., Blake, D. R., Homeyer, C. R., Brune, W. H., Zhang, L., Mao, J., Ren, X., Ryerson, T. B., Pollack, I. B., Peischl, J., Cohen, R. C., Nault, B. A., Huey, L. G., Liu, X., and Cantrell, C. A.: Convective transport and scavenging of peroxides by thunderstorms observed over the central US during DC3, J. Geophys. Res.-Atmos., 121, 4272-4295, 2016. 
Bernt, T., Scholz, W., Mentler, B., Fischer, L., Herrmann, H., Kumala, M., and Hansel, A.: Accretion Product Formation from Self- and Cross-Reactions of $\mathrm{RO}_{2}$ Radicals in the Atmosphere, Angew. Chem. Int. Edit., 57, 3820-3824, https://doi.org/10.1002/anie.201710989, 2018.

Brune, W. H., Baier, B. C., Thomas, J., Ren, X., Cohen, R. C., Pusede, S. E., Browne, E. C., Goldstein, A. H., Gentner, D.R., Keutsch, F. N., Thornton, J. A., Harrold, S., Lopez-Hilfiker, F. D., and Wennberg, P. O.:, Ozone production chemistry in the presence of urban plumes, Faraday Discuss., 189, 169-189, 2016.

Burkholder, J. B., Sander, S. P., Abbatt, J., Barker, J. R., Huie, R. E., Kolb, C. E., Kurylo, M. J., Orkin, V. L., Wilmouth, D. M., and Wine, P. H.: Chemical Kinetics and Photochemical Data for Use in Atmospheric Studies, Evaluation No. 18, JPL Publication 15-10, Jet Propulsion Laboratory, Pasadena, https://doi.org/10.13140/RG.2.1.2504.2806, 2015.

Cazorla, M., Wolfe, G. M., Bailey, S. A., Swanson, A. K., Arkinson, H. L., and Hanisco, T. F.: A new airborne laser-induced fluorescence instrument for in situ detection of formaldehyde throughout the troposphere and lower stratosphere, Atmos. Meas. Tech., 8, 541-552, https://doi.org/10.5194/amt-8-541-2015, 2015.

Chatfield, R. B. and Crutzen, P. J.: Sulfur dioxide in remote oceanic air: Cloud transport of reactive precursors, J. Geophys. Res., 89, 7111-7132, https://doi.org/10.1029/JD089iD05p07111, 1984.

Chen, S., Brune, W. H., Oluwole, O. O., Kolb, C. E., Bacon, F., Li, G. Y., and Rabitz, H.: Global Sensitivity Analysis of the Regional Atmospheric Chemical Mechanism: An Application of Random Sampling-High Dimensional Model Representation to Urban Oxidation Chemistry, Environ. Sci. Technol., 46, 1116211170, https://doi.org/10.1021/es301565w, 2012.

Christian, K. E., Brune, W. H., and Mao, J.: Global sensitivity analysis of the GEOS-Chem chemical transport model: ozone and hydrogen oxides during ARCTAS (2008), Atmos. Chem. Phys., 17, 3769-3784, https://doi.org/10.5194/acp-17-3769-2017, 2017.

Colman, J. J., Swanson, A. J., Meinardi, S., Sive, B. C., Blake, D. R., and Rowland, F. S.: Description of the Analysis of a Wide Range of Volatile Organic Compounds in Whole Air Samples Collected during PEM-Tropics A and B, Anal. Chem., 73, 37233731, 2001.

Commane, R., Floquet, C. F. A., Ingham, T., Stone, D., Evans, M. J., and Heard, D. E.: Observations of $\mathrm{OH}$ and $\mathrm{HO}_{2}$ radicals over West Africa, Atmos. Chem. Phys., 10, 8783-8801, https://doi.org/10.5194/acp-10-8783-2010, 2010.

Crounse, J. D., McKinney, K. A., Kwan, A. J., and Wennberg, P. O.: Measurement of gas-phase hydroperoxides by chemical ionization mass spectrometry, Anal. Chem., 78, 6726-6732, 2006.

Day, D. A., Woolridge, P. J., Dillon, M. B., Thornton, J. A., and Cohen, R. C.: A thermal dissociation laser-induced fluorescence instrument for in situ detection of $\mathrm{NO}_{2}$, peroxy nitrates, alkyl nitrates, and $\mathrm{HNO}_{3}$, J. Geophys. Res., 107, 4046-4053, 2002.

Faloona, I., Tan, D., Brune, W., Jaegle, L., Jacob, D., Kondo, Y., Koike, M., Chatfield, M., Pueschel, R., Ferry, G., Sachse, G., Vay, S., Anderson, B., Hannon, J., and Fuelberg, H.: Observations of HOx and its relationship with NOx in the upper troposphere during SONEX, J. Geophys. Res., 105, 3771-3783. 2000.

Faloona, I. C., Tan, D., Lesher, R. L., Hazen, N. L., Frame, C. L., Simpas, J. B., Harder, H., Martinez, M., Di Carlo, P., Ren, X. R., and Brune, W. H.: A laser-induced fluorescence instrument for detecting tropospheric $\mathrm{OH}$ and $\mathrm{HO}_{2}$ : Characteristics and calibration, J. Atmos. Chem., 47, 139-167, 2004.

Fuchs, H., Bohn, B., Hofzumahaus, A., Holland, F., Lu, K. D., Nehr, S., Rohrer, F., and Wahner, A.: Detection of $\mathrm{HO}_{2}$ by laser-induced fluorescence: calibration and interferences from $\mathrm{RO}_{2}$ radicals, Atmos. Meas. Tech., 4, 1209-1225, https://doi.org/10.5194/amt-4-1209-2011, 2011.

Fuchs, H., Novelli, A., Rolletter, M., Hofzumahaus, A., Pfannerstill, E. Y., Kessel, S., Edtbauer, A., Williams, J., Michoud, V., Dusanter, S., Locoge, N., Zannoni, N., Gros, V., Truong, F., SardaEsteve, R., Cryer, D. R., Brumby, C. A., Whalley, L. K., Stone, D., Seakins, P. W., Heard, D. E., Schoemaecker, C., Blocquet, M., Coudert, S., Batut, S., Fittschen, C., Thames, A. B., Brune, W. H., Ernest, C., Harder, H., Muller, J. B. A., Elste, T., Kubistin, D., Andres, S., Bohn, B., Hohaus, T., Holland, F., Li, X., Rohrer, F., Kiendler-Scharr, A., Tillmann, R., Wegener, R., Yu, Z., Zou, Q., and Wahner, A.: Comparison of $\mathrm{OH}$ reactivity measurements in the atmospheric simulation chamber SAPHIR, Atmos. Meas. Tech., 10, 4023-4053, https://doi.org/10.5194/amt10-4023-2017, 2017.

Hard, T. M., O’Brian, R. J., Chan, C. Y., and Mehrabzadeh, A. A.: Tropospheric free radical determination by FAGE, Environ. Sci. Technol., 18, 768-777, 1984.

Huey, L. G.: Measurement of trace atmospheric species by chemical ionization mass spectrometry: Speciation of reactive nitrogen and future directions, Mass Spectrom. Rev., 26, 166-184, 2007.

Jacob, D. J.: Heterogeneous chemistry and tropospheric ozone, Atmos. Environ., 34, 2131-2159, 2007.

Jaeglé, L., Jacob, D.J., Wennberg, P. O., Spivakowsky, C. M., Hanisco, T. F., Lanzendorf, E. J., Hintsa, E. J., Fahey, D. W., Keim, E. R., Proffitt, M. H., Atlas, E. L., Flocke, F., Schauffler, S., McElroy, C. T., Midwinter, C., Pfister, L., and Wilson, J. C.: Observed $\mathrm{OH}$ and $\mathrm{HO}_{2}$ in the upper troposphere suggest a major source from convective injection of peroxides, Geophys. Res. Lett., 24, 3181-3184, https://doi.org/10.1029/97GL03004, 1997.

Jaeglé, L., Jacob, D., Brune, W., Faloona, I., Tan, D., Heikes, B., Kondo, Y., Sachse, G., Anderson, B., Gregory, G., Singh, H., Pueschel, R., Ferry, G., Blake, D., and Shetter, R.: Photochemistry of $\mathrm{HO}_{x}$ in the upper troposphere at northern latitudes, J. Geophys. Res., 105, 3877-3892, 2000.

Jenkin, M. E., Saunders, S. M., Wagner, V., and Pilling, M. J.: Protocol for the development of the Master Chemical Mechanism, MCM v3 (Part B): tropospheric degradation of aromatic volatile organic compounds, Atmos. Chem. Phys., 3, 181-193, https://doi.org/10.5194/acp-3-181-2003, 2003.

Kanaya, Y., Cao, R., Akimoto, H., Fukuda, M., Komazaki, Y., Yokouchi, Y., Koike, M., Tanimoto, H., Takegawa N., and Kondo, Y:: Urban photochemistry in central Tokyo: 1. Observed and modeled $\mathrm{OH}$ and $\mathrm{HO}_{2}$ radical concentrations during the winter and summer of 2004, J. Geophys. Res., 112, D21312, https://doi.org/10.1029/2007jd008670, 2007.

Kovacs, T. and Brune, W.: Total OH Loss Rate Measurement, J. Atmos. Chem., 39, 105-122, 2001.

Kubistin, D., Harder, H., Martinez, M., Rudolf, M., Sander, R., Bozem, H., Eerdekens, G., Fischer, H., Gurk, C., Klüpfel, T., Königstedt, R., Parchatka, U., Schiller, C. L., Stickler, A., Taraborrelli, D., Williams, J., and Lelieveld, J.: Hydroxyl radicals in the tropical troposphere over the Suriname rainforest: comparison of measurements with the box model MECCA, At- 
mos. Chem. Phys., 10, 9705-9728, https://doi.org/10.5194/acp10-9705-2010, 2010.

Lakey, P. S. J, George, I. J., Baeza-Romero, M. T., Whalley, L. K., and Heard, D. E.: Organics Substantially Reduce $\mathrm{HO}_{2}$ Uptake onto Aerosols Containing Transition Metal ions, J. Phys. Chem. A, 120, 1421-1430, https://doi.org/10.1021/acs.jpca.5b06316, 2015.

Lakey, P. S. J., Berkemeier, T., Krapf, M., Dommen, J., Steimer, S. S., Whalley, L. K., Ingham, T., Baeza-Romero, M. T., Pöschl, U., Shiraiwa, M., Ammann, M., and Heard, D. E.: The effect of viscosity and diffusion on the $\mathrm{HO}_{2}$ uptake by sucrose and secondary organic aerosol particles, Atmos. Chem. Phys., 16, 1303513047, https://doi.org/10.5194/acp-16-13035-2016, 2016.

Logan, J. A., Prather, M. J., Wofsy, S. C., and McElroy: M. B., Tropospheric chemistry: A global perspective, J. Geophys. Res., 86, 7210-7254, 1981.

Mao, J., Ren, X., Brune, W. H., Olson, J. R., Crawford, J. H., Fried, A., Huey, L. G., Cohen, R. C., Heikes, B., Singh, H. B., Blake, D. R., Sachse, G. W., Diskin, G. S., Hall, S. R., and Shetter, R. E.: Airborne measurement of $\mathrm{OH}$ reactivity during INTEX-B, Atmos. Chem. Phys., 9, 163-173, https://doi.org/10.5194/acp-9163-2009, 2009.

Mao, J., Jacob, D. J., Evans, M. J., Olson, J. R., Ren, X., Brune, W. H., Clair, J. M. St., Crounse, J. D., Spencer, K. M., Beaver, M. R., Wennberg, P. O., Cubison, M. J., Jimenez, J. L., Fried, A., Weibring, P., Walega, J. G., Hall, S. R., Weinheimer, A. J., Cohen, R. C., Chen, G., Crawford, J. H., McNaughton, C., Clarke, A. D., Jaeglé, L., Fisher, J. A., Yantosca, R. M., Le Sager, P., and Carouge, C.: Chemistry of hydrogen oxide radicals $\left(\mathrm{HO}_{x}\right)$ in the Arctic troposphere in spring, Atmos. Chem. Phys., 10, 58235838, https://doi.org/10.5194/acp-10-5823-2010, 2010.

Mao, J., Ren, X., Zhang, L., Van Duin, D. M., Cohen, R. C., Park, J.-H., Goldstein, A. H., Paulot, F., Beaver, M. R., Crounse, J. D., Wennberg, P. O., DiGangi, J. P., Henry, S. B., Keutsch, F. N., Park, C., Schade, G. W., Wolfe, G. M., Thornton, J. A., and Brune, W. H.: Insights into hydroxyl measurements and atmospheric oxidation in a California forest, Atmos. Chem. Phys., 12, 8009-8020, https://doi.org/10.5194/acp-12-8009-2012, 2012.

Martinez, M, Harder, H., Kovacs, T. A., Simpas, J. B., Bassis, J., Lesher, R., Brune, W. H., Frost, G. J., Williams, E. J., Stroud, C. A., Jobson, B. T., Roberts, J. M., Hall, S. R., Shetter, R. E., Wert, B., Fried, A., Alicke, B., Stutz, J., Young, V. L., White, A. B., and Zamora, R. J.: $\mathrm{OH}$ and $\mathrm{HO}_{2}$ concentrations, sources, and loss rates during the Southern Oxidants Study in Nashville, Tennessee, summer 1999, J. Geophys. Res.-Atmos., 108, 4617, https://doi.org/10.1029/2003JD003551, 2003.

Mauldin III, R. L., Tanner, D. J., Frost, G. J., Chen, G., Prevot, A. S. H., Davis, D. D., and Eisele, F. L.: OH measurements during ACE-1: observations and model comparisons, J. Geophys. Res.Atmos., 103, 16713-16729, 1998.

Mielke, L. H., Erickson, D. E., McLuckey, S. A., Müller, M., Wisthaler, A., Hansel, A., and Shepson, P. B.: Development of a Proton-Transfer Reaction-Linear Ion Trap Mass Spectrometer for Quantitative Determination of Volatile Organic Compounds, Anal. Chem., 80, 8171-8177, https://doi.org/10.1021/ac801328d, 2008.

Nault, B. A., Garland, C., Wooldridge, P. J., Brune, W. H., Campuzano-Jost, J., Crounse, J. D., Day, D. A., Dibb, J., Hall, S. R., Huey, L. G., Jimenez, J. L., Liu, X. X., Mao, J. Q., Mikoviny,
T., Peischl, J., Pollack, I. B., Ren, X. R., Ryerson, T. B., Scheuer, E., Ullmann, K., and Wennberg, P. O., Wisthaler, A., Zhang, L., and Cohen, R.C.: Observational Constraints on the Oxidation of $\mathrm{NO}_{\mathrm{x}}$ in the Upper Troposphere, J. Phys. Chem. A, 120, 14681478, 2016.

Nault, B. A., Laughner, J. L., Wooldridge, P. J., Crounse, J. D., Dibb, J., Diskin, G., and Cohen, R. C.: Lightning $\mathrm{NO}_{\mathrm{x}}$ emissions: reconciling measured and modeled estimates with updated $\mathrm{NO}_{\mathrm{x}}$ chemistry, Geophys. Res. Lett., 44, 9479-9488, https://doi.org/10.1002/2017GL074436, 2017.

Olson, J. R., Crawford, J. H., Chen, G., Fried, A., Evans, M., Jordan, C. E., Sandholm, S. T., Davis, D. D., Anderson, B. E., Avery, M. A., Barrick, J. D., Blake, D. R., Brune, W. H., Eisele, F. L., Flocke, F., Harder, H., Jacob, D. J., Kondo, Y., Lefer, B. L., Martinez M., Mauldin, R. L., Sachse, G. W., Shetter, R. E., Singh, H. B., Talbot, R. W., and Tan D.:, Testing fast photochemical theory during TRACE-P based on measurements of $\mathrm{OH}, \mathrm{HO}_{2}$, and $\mathrm{CH}_{2} \mathrm{O}$, J. Geophys. Res.-Atmos., 109, D15S10, https://doi.org/10.1029/2003JD004278, 2004.

Olson, J. R., Crawford, J. H., Chen, G., Brune, W. H., Faloona, I. C., Tan, D., Harder, H., and Martinez, M.: A reevaluation of airborne HOx observations from NASA field campaigns, J. Geophys. Res.-Atmos., 111, D10301, https://doi.org/10.1029/2005JD006617, 2006.

Olson, J. R., Crawford, J. H., Brune, W., Mao, J., Ren, X., Fried, A., Anderson, B., Apel, E., Beaver, M., Blake, D., Chen, G., Crounse, J., Dibb, J., Diskin, G., Hall, S. R., Huey, L. G., Knapp, D., Richter, D., Riemer, D., Clair, J. St., Ullmann, K., Walega, J., Weibring, P., Weinheimer, A., Wennberg, P., and Wisthaler, A.: An analysis of fast photochemistry over high northern latitudes during spring and summer using in-situ observations from ARCTAS and TOPSE, Atmos. Chem. Phys., 12, 6799-6825, https://doi.org/10.5194/acp-12-6799-2012, 2012.

Pickering, K. E., Thompson, A. M., Dickerson, R. R., Luke, W. T., McNamara, D. P., Greenberg, J. P., and Zimmerman, P. R.: Model calculations of tropospheric ozone production potential following observed convective events, J. Geophys. Res.-Atmos., 95, 14049-14062, https://doi.org/10.1029/JD095iD09p14049, 1990.

Pollack, I. B., Lerner, B. M., and Ryerson, T. B.: Evaluation of ultraviolet light-emitting diodes for detection of atmospheric $\mathrm{NO}_{2}$ by photolysis-chemiluminescence, J. Atmos. Chem., 65, 111-125, https://doi.org/10.1007/s10874-011-9184-3, 2011.

Pollack, I. B., Homeyer, C. R., Ryerson, T. B., Aikin, K. C., Peichl, J., Apel, E. C., Campos, T., Flocke, F., Hornbrook, R. S., Knapp, D. J., Montzka, D. D., Weinheimer, A. J., Riemer, D., Diskin, G., Sachse, G., Mikoviny, T., Wisthaler, A., Bruning, E., MacGorman, D., Cummings, K. A., Pickering, K. E., Huntrieser, H., Lichtenstern, M., Schlager, H., and Barth, M. C.: Airborne quantification of upper tropospheric $\mathrm{NO}_{x}$ production from lightning in deep convective storms over the United States Great Plains, J. Geophys. Res.-Atmos., 121, 2002-2028, https://doi.org/10.1002/2015JD023941, 2016.

Ravetta, F., Jacob, D. J., Brune, W. H., Tan, D., Faloona, I. F., Heikes, B. J., Anderson, B., Blake, D. R., Gregory, G. L., Sachse, G. W., Sandholm, S. T., Shetter, R. E., Singh, H. E., and Talbot, R. W.: Experimental evidence for the importance of convected methylhydroperoxide as a source of hydrogen oxide $\left(\mathrm{HO}_{x}\right)$ radicals in the tropical upper troposphere, J. Geophys. Res.-Atmos., 106, 32709-32716, 2001. 
Regelin, E., Harder, H., Martinez, M., Kubistin, D., Tatum Ernest, C., Bozem, H., Klippel, T., Hosaynali-Beygi, Z., Fischer, H., Sander, R., Jöckel, P., Königstedt, R., and Lelieveld, $\mathrm{J} .: \mathrm{HO}_{x}$ measurements in the summertime upper troposphere over Europe: a comparison of observations to a box model and a 3-D model, Atmos. Chem. Phys., 13, 10703-10720, https://doi.org/10.5194/acp-13-10703-2013, 2013.

Ren, X. R., Harder, H., Martinez, M., Lesher, R. L., Oliger, A., Shirley, T., Adams, J., Simpas, J. B., andBrune, W.H.: $\mathrm{HO}_{x}$ concentrations and $\mathrm{OH}$ reactivity observations in New York City during PMTACS-NY2001, Atmos. Environ., 37, 3627-3637, 2003.

Ren, X. R., Olson, J. R., Crawford, J. H., Brune, W. H., Mao, J. Q., Long, R. B., Chen, Z., Chen, G., Avery, M. A., Sachse, G. W., Barrick, J. D., Diskin, G. S., Huey, L. G., Fried, A., Cohen, R. C., Heikes, B., Wennberg, P. O., Singh, H. B., Blake, D. R., and Shetter, R. E.: $\mathrm{HO}_{x}$ chemistry during INTEX-A 2004: Observation, model calculation, and comparison with previous studies, J. Geophys. Res.-Atmos., 113, D05319, https://doi.org/10.1029/2007JD009166, 2008.

Ren, X., Mao, J., Brune, W. H., Cantrell, C. A., Mauldin III, R. L., Hornbrook, R. S., Kosciuch, E., Olson, J. R., Crawford, J. H., Chen, G., and Singh, H. B.: Airborne intercomparison of $\mathrm{HO}_{x}$ measurements using laser-induced fluorescence and chemical ionization mass spectrometry during ARCTAS, Atmos. Meas. Tech., 5, 2025-2037, https://doi.org/10.5194/amt-5-2025-2012, 2012.

Ridley, B. A., Dye, J., Walega, J. G., Zheng, J., Grahek, F. E., and Rison, W.: On the production of active nitrogen by thunderstorms over New Mexico, J. Geophys. Res.-Atmos., 101, 20985-21005, https://doi.org/10.1029/96JD01706, 1996.

Ryerson, T. B., Williams, E. J., and Fehsenfeld, F. C.: An efficient photolysis system for fast-response $\mathrm{NO}_{2}$ measurements, J. Geophys. Res., 105, 26447-26461, 2000.

Sachse, G. W., Collins, J. E., Hill, G. F., Wade, L. O., Burney, L. G., and Ritter, J. A.: Airborne tunable diode-laser sensor for high-precision concentration and flux measurements of carbonmonoxide and methane, Proc. SPIE, 1433, 157-166, 1991.

Saunders, S. M., Jenkin, M. E., Derwent, R. G., and Pilling, M. J.: Protocol for the development of the Master Chemical Mechanism, MCM v3 (Part A): tropospheric degradation of nonaromatic volatile organic compounds, Atmos. Chem. Phys., 3, 161-180, https://doi.org/10.5194/acp-3-161-2003, 2003.

Shirley, T. R., Brune, W. H., Ren, X., Mao, J., Lesher, R., Cardenas, B., Volkamer, R., Molina, L. T., Molina, M. J., Lamb, B., Velasco, E., Jobson, T., and Alexander, M.: Atmospheric oxidation in the Mexico City Metropolitan Area (MCMA) during April 2003, Atmos. Chem. Phys., 6, 27532765, https://doi.org/10.5194/acp-6-2753-2006, 2006.

Schumann, U. and Huntrieser, H.: The global lightning-induced nitrogen oxides source, Atmos. Chem. Phys., 7, 3823-3907, https://doi.org/10.5194/acp-7-3823-2007, 2007.

Stone, D., Evans, M. J., Commane, R., Ingham, T., Floquet, C. F. A., McQuaid, J. B., Brookes, D. M., Monks, P. S., Purvis, R., Hamilton, J. F., Hopkins, J., Lee, J., Lewis, A. C., Stewart, D., Murphy, J. G., Mills, G., Oram, D., Reeves, C. E., and Heard, D. E.: $\mathrm{HO}_{x}$ observations over West Africa during AMMA: impact of isoprene and $\mathrm{NO}_{x}$, Atmos. Chem. Phys., 10, 9415-9429, https://doi.org/10.5194/acp-10-9415-2010, 2010.
Stone, D., Whalley, L. K., and Heard, D. E.: Tropospheric OH and $\mathrm{HO}_{2}$ radicals: field measurements and model comparisons, Chem. Soc. Rev., 41, 6348-6404, 2012.

Tan, D., Faloona, I., Simpas, J. B., Brune, W., Olson, J., Crawford, J., Sandholm, S., Guan, H.-W., Vaughn, T., Mastromarino, J., Sachse, G., Vay, S., Podolske, J., Avery, M., Heikes, B., Snow, J., and Singh, $\mathrm{H} .: \mathrm{OH}$ and $\mathrm{HO}_{2}$ in the remote tropical Pacific: results from PEM-Tropics B, J. Geophys. Res., 106, 32667-32681, 2001.

Tang, M. J., Cox, R. A., and Kalberer, M.: Compilation and evaluation of gas phase diffusion coefficients of reactive trace gases in the atmosphere: volume 1. Inorganic compounds, Atmos. Chem. Phys., 14, 9233-9247, https://doi.org/10.5194/acp14-9233-2014, 2014.

Thompson, A. M. and Stewart, R. W.: Effect of chemical kinetics uncertainties on calculated constituents in a tropospheric photochemical model, J. Geophys. Res.-Atmos., 96, 13089-13108, https://doi.org/10.1029/91JD01056, 1991.

Thornton, J. A., Wooldridge, P. J., and Cohen, R. C.: Atmospheric $\mathrm{NO}_{2}$ : In situ Laser-Induced Fluorescence Detection at Parts per Trillion Mixing Ratios, Anal. Chem., 72, 528-539, 2000.

Thornton, J. A., Jaeglé, L., and McNeill, V. F.: Assessing known pathways for $\mathrm{HO}_{2}$ loss in aqueous atmospheric aerosols: Regional and global impacts on tropospheric oxidants, J. Geophys. Res.-Atmos., 113, D05303, https://doi.org/10.1029/2007JD009236, 2008.

Vay, S. A., Anderson, B. E., Sachse, G. W., Collins Jr., J. E., Podolske, J. R., Twohy, C. W., Gandrud, B., Chan, K. R., Baughcum, S. L., and Wallio, H. A.: DC-8-based observations of aircraft $\mathrm{CO}, \mathrm{CH}_{4}, \mathrm{~N}_{2} \mathrm{O}$, and $\mathrm{H}_{2} \mathrm{O}(\mathrm{g})$ emission indices during SUCCESS, Geophys. Res. Lett., 25, 1717-1720, 1998.

Wennberg, P. O., Hanisco, T. F., Jaegle, L., Jacob, D. J., Hintsa, E. J., Lanzendorf, E. J., Anderson, J. G., Gao, R.-S., Keim, E. R., Donnelly, S. G., Del Negro, L. A., Fahey, D. W., McKeen, S. A., Salawitch, R. J., Webster, C. R., May, R. D., Herman, R. L., Proffitt, M. H., Margitan, J. J., Atlas, E. L., Schauffler, S. M., Flocke, F., McElroy, C. T., and Bui, T. P.: Hydrogen radicals, nitrogen radicals, and the production of $\mathrm{O}_{3}$ in the upper troposphere, Science, 279, 49-53, 1998.

Whalley, L. K., Stone, D., George, I. J., Mertes, S., van Pinxteren, D., Tilgner, A., Herrmann, H., Evans, M. J., and Heard, D. E.: The influence of clouds on radical concentrations: observations and modelling studies of $\mathrm{HO}_{x}$ during the Hill Cap Cloud Thuringia (HCCT) campaign in 2010, Atmos. Chem. Phys., 15, 3289-3301, https://doi.org/10.5194/acp-15-3289-2015, 2015.

Wolfe, G. M.: F0AM Box Model, available at: https://sites.google. com/site/wolfegm/models, 2017.

Wolfe, G. M., Marvin, M. R., Roberts, S. J., Travis, K. R., and Liao, J.: The Framework for 0-D Atmospheric Modeling (F0AM) v3.1, Geosci. Model Dev., 9, 3309-3319, https://doi.org/10.5194/gmd9-3309-2016, 2016.

York, D., Evensen, N., Martinez, M., and Delgado, J.: Unified equations for the slope, intercept, and standard errors of the best straight line, Am. J. Phys., 72, 367-375, https://doi.org/10.1119/1.1632486, 2004. 